\title{
Tethyan versus Iberian extension during the Cretaceous period in the eastern Iberian Peninsula: insights from magnetic fabrics
}

\author{
C. García-Lasanta ${ }^{*}$, T. Román-Berdiel ${ }^{1}$, B. Oliva-Urcia ${ }^{2}$, A. M. Casas ${ }^{1}$, I. Gil-Peña ${ }^{3}$, \\ F. Speranza ${ }^{4}$ \& T. Mochales ${ }^{3,4}$ \\ ${ }^{1}$ Departamento de Ciencias de la Tierra, Universidad de Zaragoza, Pedro Cerbuna 12, 50009 Zaragoza, Spain \\ 2 Departamento de Geología y Geoquímica, Universidad Autónoma de Madrid, Francisco Tomás y Valiente 7, 28049 \\ Madrid, Spain \\ ${ }^{3}$ Instituto Geológico y Minero de España, Ríos Rosas 23, 28003 Madrid, Spain \\ ${ }^{4}$ Istituto Nazionale di Geofisica e Vulcanologia, Via di Vigna Murata 605, 00143 Rome, Italy \\ *Correspondence: lasanta@unizar.es
}

\begin{abstract}
This work investigates how anisotropy of magnetic susceptibility (AMS) recorded the strain related to the Early Cretaceous extensional processes in synrift sediments of the Maestrat basin (eastern Spain). Forty-two sites, distributed throughout the Lower Cretaceous sequence with dominant gentle dips, were sampled. Minerals contributing to the AMS are mainly phyllosilicates. The parallelism between magnetic and sedimentary foliation seems to indicate that a primary (synsedimentary and early diagenetic) magnetic fabric was preserved at $84 \%$ of sites. Consequently, preferred orientations of magnetic lineations are interpreted to record the effect of extensional processes coeval with sedimentation and diagenesis during this period. At these 35 sites, two main magnetic lineation orientations are found, delimiting two large domains: a NE-SW orientation prevailing in the NW sector of the basin (parallel to the extension direction of the Iberian basin), and NW-SE to NNW-SSE orientations to the SE (parallel to the extension direction controlling the western Tethys margin). Directional variability demonstrates that the Maestrat basin is located at the boundary between two domains (Iberian and Tethyan) undergoing different plate-scale extensional processes. The subsequent Cenozoic tectonic inversion affected the synsedimentary magnetic fabrics at only a few sites at the borders of the basin, where compressive features are more developed.
\end{abstract}

Received 2 June 2015; revised 11 August 2015; accepted 11 August 2015

The interpretation of geological processes at a regional scale in weakly deformed rocks from extensional basins can be hindered by the lack of deformational structures. Even after performing structural and sedimentological studies, ambiguities in the characterization of the deformation-driving mechanisms and their causes can still arise. This shortcoming is magnified when successive tectonic events affect the same rocks. The use of indirect techniques such as magnetic fabric analysis becomes essential when a complex deformation history makes difficult the direct characterization of consecutive deformation events (e.g. Soto et al. 2007, 2008; Oliva-Urcia et al. 2010a,b, 2013; García-Lasanta et al. 2014).

The synrift Cretaceous units of the Maestrat basin (SE Iberian Range, Fig. 1) constitute a clear example of sedimentary rocks affected by successive tectonic processes. The Iberian Range was an intraplate basin subjected to a positive tectonic inversion during Cenozoic times (e.g. Guimerà et al. 2004) in relation to the Alpine orogeny. The stages predating inversion were characterized by extension and sedimentation related to rifting. Up to $5000 \mathrm{~m}$ of synrift sediments accumulated during the Early Cretaceous in the Maestrat basin (Salas \& Casas 1993; Garcia et al. 2014; and references therein). During the subsequent tectonic inversion, deformation was completely controlled by fault reactivation (Liesa 2000; Antolín-Tomás et al. 2007). Folds developed near the western and, more noteworthy, northern borders of the region (Fig. 1). Apart from some local exceptions, no penetrative structures (i.e. cleavage) linked to compression appear at outcrop scale.

Anisotropy of magnetic susceptibility (AMS) is a commonly used technique applied to petrofabric studies in cases in which either there is a lack of kinematic indicators or there are complex tectonic circumstances. It can provide valuable information about the rock fabric, as a parallelism between the orientation of the
AMS ellipsoid and the sedimentary and/or tectonic fabrics of rocks has been demonstrated (e.g. Borradaile \& Tarling 1981; Kligfield et al. 1983; Tarling \& Hrouda 1993; Borradaile \& Henry 1997; Mattei et al. 1999; Borradaile \& Jackson 2004). The orientation of the AMS ellipsoid registers the tectonic regime acting from the very beginning of diagenesis (e.g. Kissel et al. 1986; Mattei et al. 1999; Sagnotti et al. 1999; Borradaile \& Jackson 2004; Cifelli et al. 2005; Larrasoaña et al. 2011). Therefore, a primary magnetic fabric can be purely sedimentary or can reflect the tectonic conditions acting during sedimentation and early diagenesis. However, tectonic interpretations based on AMS are valid whenever a proper control over other parameters is achieved. These parameters include magnetic mineralogy, sedimentary conditions and tectonic overprinting of subsequent tectonic stages on the primary fabric (e.g. Parés et al. 1999; Soto et al. 2007, 2008; Oliva-Urcia et al. 2013).

The goal of this work is to characterize the extensional context for Lower Cretaceous sediments of the Maestrat basin using AMS techniques. This analysis is accompanied by a detailed analysis of magnetic mineralogy of the studied rocks and a determination of the magnetic fabric origin in relation to the sedimentary and extensional processes acting during the rifting stage.

\section{Geological context}

Two major rifting stages affected the Iberian intracratonic basin during the Mesozoic. The first stage is related to the deposition of Permian and Triassic units. Despite the significance of this event, its sedimentary vestiges in the Maestrat area are scarce. The second major phase of tectonic subsidence occurred during the Late Jurassic-Early Cretaceous (e.g. Martín-Martín et al. 2013, and 


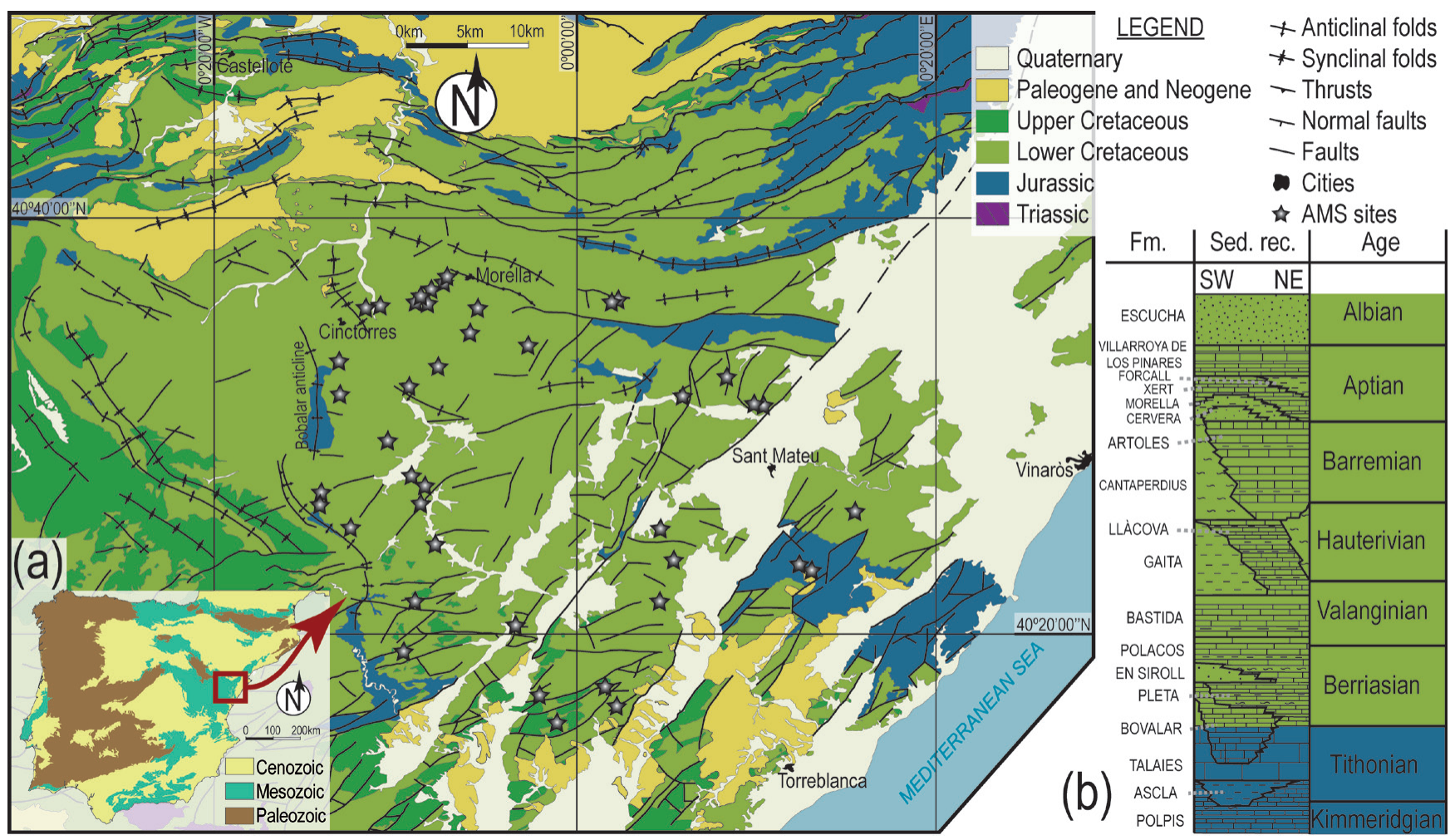

Fig. 1. (a) Geological sketch of the Maestrat basin and its location in the Iberian Peninsula, including the location of the sampling sites (simplified from GEODE 2013). (b) Simplified stratigraphic reconstruction of the synrift series in the Maestrat basin (modified from Salas et al. 2001).

references therein) and is the subject of this study. This event coincided with rift propagation from the Middle Atlantic towards the north and the consequent opening of the Bay of Biscay (e.g. Ziegler 1989; Olivet 1996; Mas \& García 2004). During the same period, the opening of the Tethys Ocean resulted in the destruction of the carbonate Jurassic platform in the eastern Iberian basin (MartínChivelet et al. 2002). These extensional events have been related to the development of the different branches of an RRR (ridgeridge-ridge) triple junction located in the westernmost limit of the Tethys, and the Iberian basin is considered to represent the aulacogen branch of this triple junction (Álvaro et al. 1979). As a consequence of these processes, a new system of strongly subsiding extensional basins formed within the Iberian domain, over the preexisting Triassic rifts (e.g. Salas et al. 2001; Mas \& García 2004). During the Tithonian-Berriasian (between 150 and $130 \mathrm{Ma}$ ) rifting had extended across the whole Iberian basin. Syntectonic deposits of both continental and shallow-marine origin (Soria et al. 1995, 2000) infilled the new sedimentary basins and partly lapped onto the previous structural highs (Salas \& Casas 1993).

The Maestrat basin is located in the eastern boundary of the Iberian Range (Fig. 1) in an approximately central position within the triple junction area (Álvaro et al. 1979). Therefore, it underwent the earliest part of the Late Jurassic-Early Cretaceous rifting of the Iberian basin. The rifting process was controlled here by large-scale NW-SE and NE-SW faults conditioned by the trends of the pre-existing late Variscan structures (Álvaro et al. 1979; Liesa et al. 1996; Salas et al. 2001; Capote et al. 2002). However, detailed analyses show a more complex pattern of fault orientations (Antolín-Tomás et al. 2007), probably responding to the influence of the regional processes in the Maestrat area: the development of the Tethys Ocean, located to the SE (Salas \& Casas 1993) and the opening of the Bay of Biscay and the Pyrenean Trough, located to the NW and the north of the studied basin, respectively (Ziegler 1989). Mesoscale and outcrop-scale observations (Antolín-Tomás et al. 2007) indicate the predominance of two conjugate sets of faults with WNW-ESE to NW-SE and NNE-SSW to NE-SW strikes. Although recorded throughout the basin, these sets are more prevalent westwards and eastwards, respectively. A secondary system defined by two other sets of fault planes oriented north-south and east-west was also documented by Antolín-Tomás et al. (2007). These data concur with previous palaeostress analyses that interpreted a radial extensional regime for the Early Cretaceous synrift deposits, with two subtle extension directions: NNE-SSW in the north and western margins (Aranda \& Simón 1993; Rodríguez-López et al. 2006) and ESE-WNW to the south and east (e.g. Antolín-Tomás et al. 2007).

The basal unconformity separating the synrift sequence from the pre-rift units constitutes the shortest basal gap along the Early Cretaceous Iberian system of basins (Aurell 1991). The upper boundary of the synrift sequence is an intra-Albian unconformity recorded just before the post-rift thermal stage (Alonso et al. 1993; Salas et al. 2001). Around $5000 \mathrm{~m}$ of synrift sediments were deposited in the Maestrat basin during the Early Cretaceous rifting stage (Fig. 1), generally in shallow-marine environments. However, slight variations occurred though time associated with repeated transgression cycles in the Tethys (Salas \& Casas 1993). The synrift series started with distal ramp sediments during the Kimmeridgian and $1000 \mathrm{~m}$ thick shallower platform sediments during the Tithonian-Berriasian. From the beginning of the Valanginian and coinciding with a drastic attenuation in the rate of subsidence, marine deposits were restricted to the basin depocentre, coinciding with fluvial influence toward its borders (e.g. Mas \& García 2004, and references therein). Similar patterns of sedimentation continued during the Hauterivian and Barremian, when more than $1000 \mathrm{~m}$ thickness of shallow carbonate platform sediments lapped onto the previous series (Artoles Fm), changing to freshwater deposits towards the basin margins. The lower Aptian deposits are fluvio-deltaic series of around $100 \mathrm{~m}$ thickness (Morella Fm), which were deposited unconformably in relation to a significant sea-level drop. They consist of heterogeneous materials 

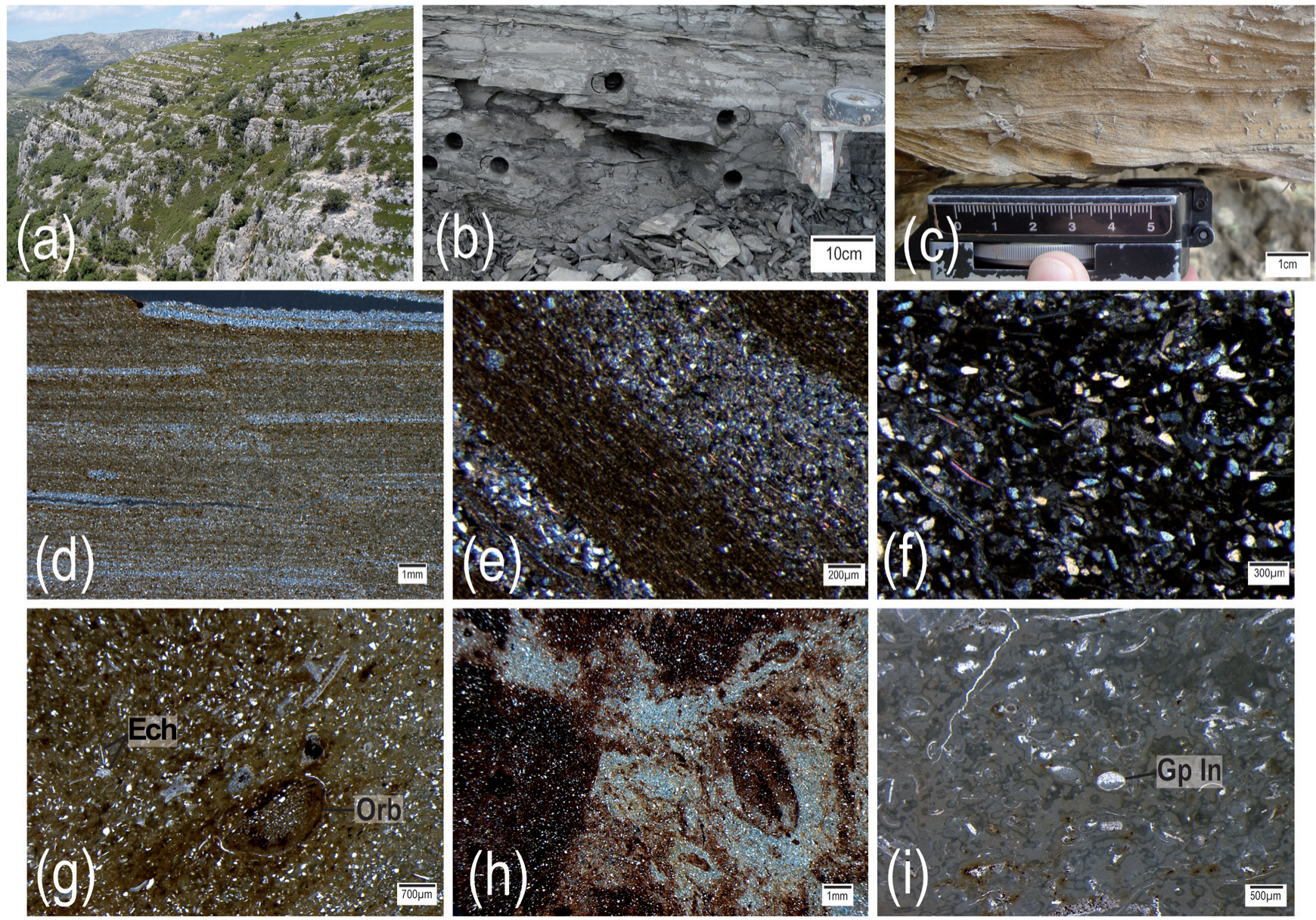

Fig. 2. (a) General view of Lower Cretaceous units of the Maestrat basin. (b) Detailed image of site MO13, where horizontal lamination is observed. (c) Cross-bedding in layers situated around $3 \mathrm{~m}$ above site MO5 in the stratigraphic profile. (d-h) Thin-section images. (d) Micro-scale normal fault cutting the sedimentary lamination (sample BE3-2A, crossed Nicols). (e) Phyllosilicates parallel to lamination interspersed within micrite and detrital layers (sample MO13-10A, crossed Nicols). (f) Mica crystals showing typical second-order interference colours, parallel each other and interspersed with other detrital grains (sample MO11-3B, crossed Nicols). (g) Sparse biomicrite with echinoderm plates and quills (Ech) and a large Orbitolina (Orb), oriented according to bedding (sample AL1-5A, parallel Nicols). (h) Massive texture in a sample from the Morella Fm with presence of ferruginous irregular peloids (sample MO3-6A, crossed Nicols). (i) Geopetal infill (Gp In) in ostracods included in a micritic matrix, which can be used as a polarity criterion (e.g. Wieckzorek 1979, sample AL2-1A, parallel Nicols).

including red beds of different grain sizes (Canérot 1974). Marine conditions prevailed again during the rest of the Aptian, producing the widespread deposition of up to $1100 \mathrm{~m}$ of shallow-water carbonate platform sediments (Martín-Chivelet et al. 2002; Mas \& García 2004). Lower and Middle Albian rocks are represented by up to $500 \mathrm{~m}$ of tidal-influenced deltaic sediments with coal layers (Escucha Fm, Querol et al. 1992). These sediments define the end of the rifting and the beginning of the following post-rift thermal subsidence, associated with the deposition of marine platform sediments throughout the Iberian domain (e.g. Alonso et al. 1993; Martín-Chivelet et al. 2002; Mas \& García 2004; RodríguezLópez et al. 2006).

The basin underwent tectonic inversion during the Palaeogene in response to a NNE-SSW shortening recorded along the whole Iberian Range (Guimerà 1984; Guimerà et al. 2004) associated with the convergence of the Iberian, European and African plates (e.g. Salas \& Casas 1993; Capote et al. 2002; Martín-Chivelet et al. 2002). The orientation of the main Variscan and Mesozoic extensional structures (NW-SE and NE-SW) partially conditioned the main trend of the Alpine compressive structures (Liesa et al. 1996, 2000), predominantly oriented WNW-ESE to NW-SE. Compressive structures are more common in the basin margins, towards the north and the west of the basin centre. Thrusts also rooted, as extensional faults, in the Middle and Upper Triassic evaporites and marls, and in deeper Palaeozoic detachment horizons (Roca et al. 1994; Antolín-Tomás et al. 2007). Compressional structures are rare in the central Maestrat basin, owing to the greater thickness of the synrift sequence in this area, in which strata remained generally subhorizontal (Fig. 2a and b; Canérot 1974; Simón Gómez 1984). No penetrative structures such as cleavage developed and compression produced brittle deformation only in this central area (e.g. Liesa 2000). Reactivation of NNWSSE basement structures in the eastern limit of the Maestrat basin occurred during the Neogene in response to extension and crustal thinning associated with the opening of the Valencia Trough (Simón Gómez 1984; Roca \& Guimerà 1992; Salas \& Casas 1993; Sàbat et al. 1995). The reactivation of the NNW-SSE-oriented set of faults in the eastern part of the Maestrat basin interferes with the observation of the Mesozoic rifting effect in that area (AntolínTomás et al. 2007).

\section{Methods}

This work is based on the study of magnetic susceptibility $(k)$; that is, the physical property of materials that describes the ratio of induced magnetization $(M)$ when a magnetic field $(H)$ is applied: $M=k \times H$. We studied the orientation of the anisotropy of magnetic susceptibility, which can be related to the petrofabric recorded in sediments during their geological history (e.g. Borradaile 1988; 
Table 1. Summary of magnetic scalar data

\begin{tabular}{|c|c|c|c|c|c|c|c|c|c|c|c|c|c|c|c|c|}
\hline Site & Zone & UTM East & UTM North & Age & Lithology & $n(N)$ & $\begin{array}{c}k m \\
\left(\times 10^{-}\right. \\
\left.{ }^{6} \mathrm{SI}\right)\end{array}$ & $\begin{array}{c}e \\
\left(\times 10^{-}\right. \\
\left.{ }^{6} \mathrm{SI}\right)\end{array}$ & $L$ & $e$ & $F$ & $e$ & $P j$ & $e$ & $T$ & $e$ \\
\hline AL1 & $31 \mathrm{~T}$ & X252930.46 & 4475055.04 & Hau-Bar & Mudstone & $13(17)$ & 97.4 & 12.8 & 1.003 & 0.002 & 1.016 & 0.003 & 1.020 & 0.004 & 0.725 & 0.161 \\
\hline AL2 & $31 \mathrm{~T}$ & X252129.91 & Y4478148.11 & Hau-Bar & Marl & $12(13)$ & 31.7 & 12.9 & 1.003 & 0.002 & 1.004 & 0.003 & 1.007 & 0.004 & 0.130 & 0.364 \\
\hline AL3 & $31 \mathrm{~T}$ & $\mathrm{X} 251792.16$ & Y4471436.16 & Hau-Bar & Sand medGS & $13(13)$ & 107 & 13.1 & 1.003 & 0.001 & 1.016 & 0.004 & 1.020 & 0.005 & 0.663 & 0.125 \\
\hline AL4 & $31 \mathrm{~T}$ & X248198.70 & Y4462243.52 & Hau-Bar & $\begin{array}{l}\text { Mud and Marly } \\
\text { lime }\end{array}$ & $14(14)$ & 32.9 & 14.7 & 1.003 & 0.002 & 1.006 & 0.003 & 1.010 & 0.004 & 0.368 & 0.317 \\
\hline AL5 & $31 \mathrm{~T}$ & $\mathrm{X} 247586.52$ & Y4464018.33 & LaApt & Marl & $12(12)$ & 135 & 20.4 & 1.010 & 0.006 & 1.081 & 0.010 & 1.101 & 0.013 & 0.774 & 0.115 \\
\hline AL6 & $30 \mathrm{~T}$ & X752356.79 & Y4463246.75 & LaApt & Marly limestone & $10(10)$ & 51.6 & 6.43 & 1.004 & 0.003 & 1.019 & 0.004 & 1.025 & 0.006 & 0.698 & 0.206 \\
\hline AL7.1 & $30 \mathrm{~T}$ & $\mathrm{Y} 75300643$ & $\mathrm{~V} 4$ & & Ind Merl & $11(11)$ & 191 & 34.1 & 1.002 & 0.001 & 1.055 & 0.013 & 1.065 & 0.016 & 0.930 & 0.054 \\
\hline AL7.2 & & X/53990.43 & & A & & $6(6)$ & 187 & 33.0 & 1.004 & 0.003 & 1.050 & 0.015 & 1.061 & 0.015 & 0.834 & 0.152 \\
\hline AL8 & $30 \mathrm{~T}$ & X750266.42 & Y4469601.15 & Hau-Bar & Sand smaGS & $10(20)$ & 119 & 17.5 & 1.005 & 0.002 & 1.010 & 0.002 & 1.016 & 0.003 & 0.381 & 0.167 \\
\hline BCE4 & $31 \mathrm{~T}$ & X267420.14 & Y4478789.63 & Hau-Bar & Limestone & $9(14)$ & 14.2 & 9.62 & 1.003 & 0.005 & 1.007 & 0.004 & 1.013 & 0.009 & 0.132 & 0.414 \\
\hline BE1 & $30 \mathrm{~T}$ & X744C & Y4476743.77 & Artol & Iarly limestone & $8(23)$ & 62. & 12.9 & 1.001 & 0.001 & 1.012 & 0.002 & 1.014 & 0.003 & 0.833 & 0.100 \\
\hline BE2.1 & $30 T$ & $\mathrm{X} 742$ & Y448 & Нан & $S$ & $8(10)$ & 137 & 26.3 & 1.005 & 0.003 & 1.077 & 0.016 & 1.092 & 0.020 & 0.874 & 0.059 \\
\hline BE2.2 & 501 & 70 & 44 & & & $12(12)$ & 103 & 37.1 & 1.004 & 0.003 & 1.058 & 0.022 & 1.071 & 0.025 & 0.841 & 0.136 \\
\hline BE3 & $30 \mathrm{~T}$ & X742570.17 & Y4480536.44 & Artol & Mudstone HL & $10(12)$ & 142 & 28.2 & 1.004 & 0.003 & 1.045 & 0.005 & 1.054 & 0.006 & 0.854 & 0.114 \\
\hline BE4 & $30 \mathrm{~T}$ & X741 & Y448 & Hau-Bar & Mud-Marl HL & $12(14)$ & 127 & 28.9 & 1.002 & 0.001 & 1.037 & 0.008 & 1.044 & 0.009 & 0.912 & 0.051 \\
\hline BE5 & $30 \mathrm{~T}$ & X734593.12 & Y4480931.75 & Hau-Bar & Mudstone & $10(17)$ & 152 & 22.4 & 1.005 & 0.003 & 1.055 & 0.015 & 1.067 & 0.018 & 0.830 & 0.080 \\
\hline BE6 & $30 \mathrm{~T}$ & X734585.45 & Y4479935.35 & Tith-Berr & Sand smaGS & $13(14)$ & 78.6 & 12.8 & 1.008 & 0.008 & 1.020 & 0.019 & 1.030 & 0.024 & 0.412 & 0.477 \\
\hline BE7.1 & & & & & & $10(11)$ & 58 & 22.2 & 1.002 & 0.002 & 1.012 & 0.005 & 1.016 & 0.006 & 0.721 & 0.187 \\
\hline BE7.2 & 30 & (ג/J0935. & $\mathrm{r}$ & A & IV & $5(5)$ & 32. & 3.65 & 1.003 & 0.002 & 1.018 & 0.005 & 1.022 & 0.005 & 0.724 & 0.198 \\
\hline BE8 & $30 \mathrm{~T}$ & X741 & .07 & All & Muc & $12(24)$ & 101 & 27.2 & 1.005 & 0.004 & 1.047 & 0.019 & 1.058 & 0.022 & 0.774 & 0.162 \\
\hline BE9 & $30 \mathrm{~T}$ & X74 & Y44 & LaApt & San & 12 & 76 & 25.4 & 1.003 & 0.003 & 1.028 & 0.011 & 1.035 & 0. & 0.754 & 0.210 \\
\hline JSA2 & $31 \mathrm{~T}$ & $\mathrm{X} 26$ & Y44 & Tith & & 5) & 10 & 1.94 & 1.007 & 0.004 & 1.006 & 0.003 & 1.0 & 0 . & -0.085 & 0.410 \\
\hline 14 & $31 \mathrm{~T}$ & $\mathrm{X} 2$ & Y44 & Tith & e & 0 & 27 & 10.1 & 1.004 & 0.003 & 1.015 & 0.006 & 1.020 & 0 & 0.581 & 0.279 \\
\hline XE1 & $31 \mathrm{~T}$ & $\mathrm{X} 25$ & Y44 & Iau-Bar & & 4) & 11.7 & 7.84 & 1.007 & 0.005 & 1.007 & 0.011 & 1.014 & 0 & -0 . & 0.385 \\
\hline KXE2 & $31 \mathrm{~T}$ & $\mathrm{X} 260$ & Y44 & Hau-Bar & Limestone & (18) & 30.4 & 8.93 & 1.005 & 0.003 & 1.005 & 0.003 & 1.010 & 0.006 & -0.003 & 0.402 \\
\hline KXE3 & $31 \mathrm{~T}$ & 71.47 & .07 & EaApt & Marly limestone & $9(23)$ & 26.1 & 6.73 & 1.003 & 0.002 & 1.011 & 0.005 & 1.015 & 0.006 & 0.550 & 0.309 \\
\hline MO1 & $30 \mathrm{~T}$ & X742433.96 & Y4499209.42 & EaApt & Marl & $9(19)$ & 245 & 51.9 & 1.005 & 0.002 & 1.063 & 0.011 & 1.075 & 0.013 & 0.886 & 0.061 \\
\hline $\mathrm{MO} 2$ & $30 \mathrm{~T}$ & X743416.12 & Y4499869.11 & EaApt & $\begin{array}{l}\text { Mud and Sand } \\
\text { medGS }\end{array}$ & $10(21)$ & 175 & 36.5 & 1.004 & 0.003 & 1.045 & 0.012 & 1.054 & 0.014 & 0.821 & 0.151 \\
\hline $\mathrm{MO} 3$ & $30 \mathrm{~T}$ & & & EaApt & Istone & 6) & 23 & 36.7 & 1.003 & 0.002 & 1.021 & 0.007 & 1. & 0.008 & 0.702 & 0.280 \\
\hline MO4 & $30 \mathrm{~T}$ & X741634.49 & Y4498446.34 & Artol & dstone & $17(17)$ & 176 & 17 & 1.002 & 0.001 & 1.038 & 0.005 & 1.046 & 0.006 & 0.881 & 0.067 \\
\hline MO5B & $30 \mathrm{~T}$ & 741370.50 & Y4497984.77 & EaApt & & $11(15)$ & 169 & 30.7 & 1.009 & 0.006 & 1.063 & 0.023 & 1.079 & 0.024 & 0.714 & 0.264 \\
\hline MO6.1 & $30 \mathrm{~T}$ & & & & & $8(14)$ & 200 & 19.5 & 1.002 & 0.001 & 1.019 & 0.003 & 1.023 & 0.003 & 0.792 & 0.131 \\
\hline MO6.2 & 01 & & & & & 4 & 19 & 26.6 & 1.003 & 0.002 & 1.019 & 0.002 & 1.024 & 0.002 & 0.755 & 0.182 \\
\hline MO7 & $30 \mathrm{~T}$ & & & Hau-Bar & & $7(11)$ & 89.1 & 26.5 & 1.002 & 0.001 & 1.017 & 0.004 & 1.021 & 0.005 & 0.791 & 0.149 \\
\hline I08 & $30 \mathrm{~T}$ & X73 & & aBarr & one & 15 & 95 & 53 & 1.002 & 0.001 & 1.010 & 0.006 & 1. & 0.008 & 0.666 & 0.225 \\
\hline MO9 & $31 \mathrm{~T}$ & X249 & Y4498602.41 & Hau-Bar & Mudstone & $14(18)$ & 77.9 & 14.7 & 1.002 & 0.002 & 1.006 & 0.004 & 1.009 & 0.004 & 0.423 & 0.413 \\
\hline MO10 & $31 \mathrm{~T}$ & X248832.21 & Y4498389.59 & EaApt & & $12(12)$ & 11 & 29.2 & 1.002 & 0.001 & 1.009 & 0.002 & 1.012 & 0.003 & 0.634 & 0.211 \\
\hline MO11 & $30 \mathrm{~T}$ & X750180.30 & Y4494 & Hau-Bar & nd med & $17(20)$ & 64.1 & 14.4 & 1.007 & 0.010 & 1.023 & 0.008 & 1.032 & 0.013 & 0.644 & 0.386 \\
\hline MO12 & $30 \mathrm{~T}$ & X746623.54 & Y4497759.83 & LaApt & Marly limestone & $12(12)$ & 111 & 14.9 & 1.002 & 0.001 & 1.025 & 0.004 & 1.030 & 0.005 & 0.836 & 0.100 \\
\hline MO13 & $30 \mathrm{~T}$ & X745325.50 & Y4495595.54 & LaBarr & Limestone HL & $12(17)$ & 181 & 16.1 & 1.003 & 0.002 & 1.124 & 0.015 & 1.147 & 0.018 & 0.950 & 0.370 \\
\hline MO14 & $30 \mathrm{~T}$ & X743671.90 & Y4492461.42 & Hau-Bar & Mudstone & $11(11)$ & 125 & 32.9 & 1.005 & 0.003 & 1.015 & 0.008 & 1.020 & 0.007 & 0.459 & 0.344 \\
\hline MO15 & $30 \mathrm{~T}$ & X735710.15 & Y4490033.67 & Tith-Berr & Mudstone & $10(10)$ & 154 & 16.8 & 1.002 & 0.002 & 1.018 & 0.003 & 1.023 & 0.002 & 0.754 & 0.173 \\
\hline MO16 & $31 \mathrm{~T}$ & $\mathrm{X} 254002.75$ & Y4489634.92 & Hau-Bar & $\begin{array}{l}\text { Lime and Marly } \\
\text { lime }\end{array}$ & $11(11)$ & 117 & 10.8 & 1.002 & 0.001 & 1.029 & 0.013 & 1.035 & 0.015 & 0.844 & 0.082 \\
\hline MO17 & $30 \mathrm{~T}$ & X740919.20 & Y4490919.75 & Hau-Bar & $\begin{array}{l}\text { Sand sma and } \\
\text { medGS }\end{array}$ & $12(15)$ & 75 & 13.1 & 1.003 & 0.001 & 1.024 & 0.006 & 1.030 & 0.007 & 0.739 & 0.153 \\
\hline MO1 & $30 \mathrm{~T}$ & X7. & & Hau- & Marl & & 18 & 20.3 & & 0.002 & 1.066 & 0.009 & 1.079 & 0.010 & 0.876 & 0.060 \\
\hline MO19 & 30T & X735245.09 & Y4493362.16 & Tith-Berr & Mudstone & $14(14)$ & 94.8 & 17.4 & 1.002 & 0.001 & 1.011 & 0.004 & 1.013 & 0.005 & 0.678 & 0.199 \\
\hline
\end{tabular}

For UTM coordinates datum is ETRS89. Age: Tith, Tithonian; Tith-Berr, Tithonian-Berriasian; Hau-Bar, Hauterivian-Barremian; LaBarr, Late Barremian (including Artoles Fm; Artol); EaApt, Early Aptian (including Morella Fm); LaApt, Late Aptian; Alb, Albian. Lithology: Lime, limestone; Marly lime, marly limestone; Mud, mudstone; Sand smaGS, sandstone small grain size; Sand medGS, sandstone medium grain size; HL, horizontal lamination within the sample. $n(N)$, number of cores (number of specimens); $k m$, bulk susceptibility (in SI units); $P j$, corrected anisotropy degree; $T$, shape parameter; $L$, magnetic lineation; $F$, magnetic foliation; $e$, standard deviation.

Borradaile \& Jackson 2004). A total of 42 sites, distributed throughout the outcrops of Upper Jurassic and Lower Cretaceous rocks, are used for AMS characterization. The ages of the studied rocks range from Tithonian to Early Albian, and the main lithostratigraphic units are Upper Hauterivian to Upper Aptian (Table 1). Sampled outcrops were thoroughly studied to detect sedimentary, lithological and/or structural features that could influence the magnetic fabric results. Cores were collected in the field with portable gasoline- and electric-powered drills cooled with water. They were oriented in situ and sliced into $25 \mathrm{~mm}$ diameter $\times 21 \mathrm{~mm}$ height specimens.

\section{Mineralogy and magnetic carriers}

As the total magnetic susceptibility on a rock sample is the sum of the contributions from all the magnetic phases present, mineralogy 
recognition and a careful characterization of all the magnetic carriers present in the samples and their influence on AMS orientation are essential in this type of study (Borradaile 1988; Tarling \& Hrouda 1993). The analyses performed in this case were: (1) petrographic observations, (2) temperature-dependent magnetic susceptibility analyses, (3) hysteresis loops, (4) acquisition curves of the isothermal remanent magnetization (IRM), (5) backfield IRM analyses, and (6) thermal demagnetization of the composite IRM. Each one of these techniques was applied as follows.

(1) Fifteen thin sections from all the representative rock types and the Lower Cretaceous units considered in the study were observed in a polarizing microscope, to detect potential magnetic carriers in our studied rocks and their orientation.

(2) Temperature-dependent susceptibility curves (k-T curves) were performed on powdered samples (around 25-40 mg weight) in the Magnetic Fabrics Laboratory of the University of Zaragoza, Spain. By coupling a KLY-3S susceptometer to a CSL cryogenic apparatus and to a CS3 furnace (AGICO Inc., Czech Republic), susceptibility changes were registered while heating from $-195^{\circ} \mathrm{C}$ to $0^{\circ} \mathrm{C}$ and from $40^{\circ} \mathrm{C}$ to $700^{\circ} \mathrm{C}$ and cooling back to $40^{\circ} \mathrm{C}$. A total of four low-temperature curves and 13 high-temperature curves were obtained from representative examples covering the range of lithologies in this study. Variations in susceptibility with temperature follow the Curie-Weiss law, where temperatures at which the present phases change from ferromagnetic sensu lato to paramagnetic behaviours are characteristic of each phase. These temperatures allow us to infer the presence of magnetic phases able to influence the magnetic susceptibility signal. Data processing was performed with the Cureval 8.0 software (Chadima \& Hrouda 2009).

(3) Seventeen hysteresis loops were performed on powdered samples $(0.16-0.23 \mathrm{~g})$ at room temperature in a Micromag 3900 vibrating sample magnetometer (VSM; Princeton Measurement Corp., USA) at the Paleomagnetic Laboratory of the Istituto Nazionale di Geofisica e Vulcanologia (INGV) in Rome, Italy. Progressively higher magnetic fields and subsequently decreasing fields were applied in two opposite directions up to a maximum field of $1 T$, and the induced magnetization was measured at each step. The shape of the loops does not distinguish, unambiguously, different ferromagnetic grain sizes by itself, but a simple classification within one of the known basic loop shapes will help to roughly identify a magnetic phase (Tauxe 2008).

(4) Acquisition of isothermal remanent magnetization (IRM) curves were obtained by applying stepwise increasing external magnetic fields to powdered samples and measuring their remanent magnetization at each step. Data were obtained using the Micromag 3900 VSM available at the INGV. Samples were the same as those used for the hysteresis loops, except in three cases (i.e. MO2-3, MO14-9 and MO18-14), where the original capsule had to be replaced. The shape of the obtained curve, its slope and the degree of saturation reached at $1 T$ provide information about coercivity spectra characteristic of each ferromagnetic mineral (Dunlop 1972).

(5) Backfield IRM procedures involve applying stepwise increasing magnetic fields in a direction opposed to the applied IRM field direction until the coercivity of remanence $\left(H_{\mathrm{cr}}\right)$ value is reached. This value is the magnitude of magnetic field necessary to demagnetize the sample and is useful to differentiate grain sizes in ferromagnetic phases, such as magnetite in the study by Day et al. (1977). These procedures were performed on the samples from which the IRM acquisition curves were obtained.

(6) The relative contribution of different ferromagnetic mineral phases to a specimen's remanence can be evaluated according to their coercivity and unblocking temperatures through thermal demagnetizations of composite IRM (Lowrie 1990). Procedures were developed at the INGV and consisted of applying three decreasing magnetic fields $(2000,500$ and $120 \mathrm{mT})$ to each sample with an ASC pulse magnetometer in three orthogonal directions ( $z, y$ and $x$, respectively).
This procedure induces a remanent remagnetization of the minerals present in different orthogonal directions according to their coercivity spectrum. High, intermediate and low-coercive minerals acquire a remanent magnetization parallel to the $z, y$ and $x$ directions, respectively. The next step was a thermal demagnetization of the samples, which were stepwise heated in an ASC TD48 oven (ASC Scientific, USA) from room temperature to their complete demagnetization (20, $80,120,200,300,350,400,500,550,600,625,650$ and $\left.680^{\circ} \mathrm{C}\right)$. Remanent magnetization was measured with a JR6 spinner magnetometer after each demagnetization step.

\section{AMS}

Low-field AMS (LF-AMS) at room temperature (RT) was measured in 671 samples from 42 sites with a KLY-3S Kappabridge (AGICO Inc., Czech Republic) susceptometer in the Laboratory of Magnetic Fabrics at the University of Zaragoza, Spain. The AMS can be represented as an ellipsoid defined by three principal susceptibility axes: maximum $\left(k_{\max }\right)$, intermediate $\left(k_{\text {int }}\right)$ and minimum $\left(k_{\min }\right)$. The magnitudes of these three axes are used to determine several scalar parameters, which give information about the anisotropy and shape of the magnetic ellipsoids. The corrected anisotropy degree $(P j$, Jelinek 1981) can help to describe the intensity of the preferred orientation of minerals. The shape parameter ( $T$, Jelinek 1981) can help to describe the geometry of the ellipsoid: $0<T<1$ for oblate geometries and $-1<T<0$ for prolate geometries. Magnetic lineation $\left(L=k_{\max } / k_{\text {int }}\right)$ and magnetic foliation $\left(F=k_{\text {int }} / k_{\min }\right)$ are also used for the description of the magnetic ellipsoids. In addition, the orientation of the AMS at each site was calculated by means of Jelinek (1978) statistics, which take into account the averages of all the susceptibility tensors obtained for a site to calculate the three eigenvectors that will be represented together with their associated confidence areas. For these calculations, Anisoft 4.2 (Chadima \& Jelinek 2009) was used, and data are considered before and after bedding correction at each site.

In addition, the LF-AMS of 42 samples from seven representative sites was also measured at low temperature (LT). The aim was to determine the orientation of the paramagnetic subfabrics and compare them with the results at RT, which record the effect of all magnetic fractions present in the sample. The method is based on the Curie-Weiss law, which states that paramagnetic susceptibility is enhanced at LT (e.g. Ihmlé et al. 1989; Ritcher \& Van der Pluijm 1994; Dunlop \& Özdemir 1997). This increase might overcome the signal of the ferromagnetic phases present in the sample. Samples are cooled to $77 \mathrm{~K}$ by using liquid nitrogen (e.g. Hirt \& Gehring 1991; Lüneburg et al. 1999) and measured in the KLY-3S Kappabridge susceptometer. This technique gives repeatable results (Oliva-Urcia et al. 2010a,b, 2013; García-Lasanta et al. 2014). By determining the LT/RT susceptibility ratio, as well as by comparing the orientation results of LT and RT magnetic ellipsoids, we can understand the influence of different mineral phases in the magnetic fabric orientation.

\section{Results}

\section{Outcrop-scale observations and petrographic analyses}

Sampled lithologies are presented in Table 1. The various units of the Early Cretaceous, independently from their age, show all the lithological types studied here. Sixteen out of the 42 studied sites consist of limestones and marly limestones. Marls have been identified at eight sites and mudstones have been observed at the other 15. Finally, nine sites can be described as sandstones of fine to medium grain size. All sampled lithologies show grey and yellow colours except at two sites of red mudstones (i.e. half of site MO2 and MO3). In five out of the 42 outcrops, two different lithologies 

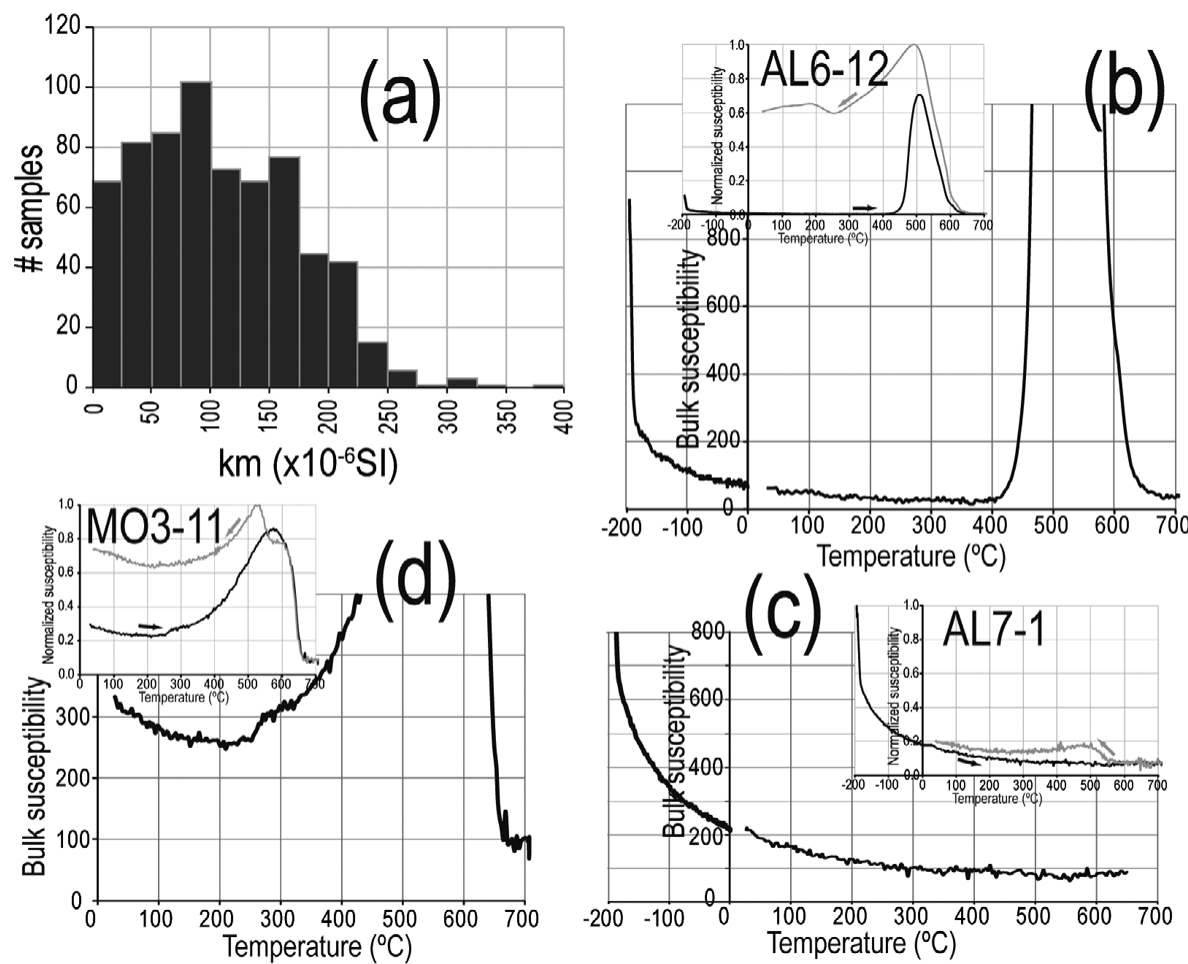

Fig. 3. (a) Frequency histogram for bulk susceptibility $(\mathrm{km})$. (b-d) Three examples of temperature $v$. susceptibility curves. Black curves, heating runs; grey curves, cooling runs. (b) and (c) each show a heating curve from -195 to $700^{\circ} \mathrm{C}$, whereas (d) shows a heating curve from 40 to $700^{\circ} \mathrm{C}$. Cooling curves are always for temperatures from 700 to $40^{\circ} \mathrm{C}$.

have been sampled at the same site (Table 1): mudstones and marly limestones, mudstones and marls, and mudstones and sandstones of different grain size.

The only sedimentary structure observed in some of the sampled levels is horizontal lamination (Fig. 2b). The thickness of laminae varies between outcrops, from a few millimetres to several centimetres. At two sites having thin laminae (AL7 and BE4), two alternating rock types (mudstones and marls) occur within the same sample.

Adjacent levels above or below the sampled localities also show horizontal lamination in most cases. In 12 out of the 42 cases, these upper and lower levels show also cross-bedding (Fig. 2c). It should be emphasized that these structures were never observed in the sampled levels. They generally appear in coarser grain-size levels in $4-5 \mathrm{~cm}$ thick sets above the sampled ones, and generally show a limited lateral continuity. Decimetre-scale cross-bedding is scarce. Palaeocurrent orientations related to these structures are generally indicated by the dip direction of the laminae (planar cross-bedding). Only at one site (BE8), where fluvial channels have been observed, could we determine that the palaeocurrent direction is parallel to the trend of those channels, and thus perpendicular to the dip direction of the cross-bedding layers. The orientations of the current flow show a strong variability (SW, SSW, NW, north, NNE, SE), without a clearly defined pattern.

Exceptionally, one of the 42 studied outcrops (site MO19) shows a tectonic foliation. This penetrative compression-related feature was observed in a layer of marls (discussed below) situated around $10 \mathrm{~m}$ below the sampled level. This area corresponds to the eastern flank of the Bobalar Anticline, which is a large-scale fold located in the western border of the study area (Fig. 1) and is associated with the Cenozoic tectonic inversion.

The observed 15 thin sections can be classified in two groups according to their detrital or calcareous content and the presence or absence of sedimentary lamination. In the first group of eight thin sections, horizontal sedimentary lamination was observed. Four out of these eight show a clear alternation between dark layers of micrite and clay minerals, and thin layers containing detrital grains (quartz and calcite), micas and clays (Fig. $2 \mathrm{~d}$ and e). The other four thin sections of the group present irregular laminae (Fig. $2 \mathrm{f}$ and g), and ubiquitously interspersed silt-size detrital grains impeding a clear division into layers. The second group of seven thin sections shows a massive texture, with different proportions of detrital content and micritic matrix (Fig. $2 \mathrm{~h}$ and i). These examples corroborate the lack of cross-bedding structures and a prevalent deposition of very small size particles in the sampled materials. These characteristics point to a low-energy depositional mechanism.

The micritic matrix is present in all the observed thin sections, to different degrees. The detrital fraction is composed of monocrystalline quartz grains, clay minerals, mica grains, calcitic fossils and other indistinguishable calcitic fragments, probably resulting from disintegration of fossils. These fossils appear in all the described textures, within the micritic matrix (Fig. 2i) and also interspersed within the quartz grains. Flat grains are present in the matrix and also interspersed within the coarser grain-size layers (Fig. 2e and f). They are usually oriented parallel to the horizontal sedimentary lamination and thus to bedding (e.g. Fig. 2e). Their second-order interference colour, which is detectable under polarized light, and their 'flake' shapes allow us to classify them as micas. Opaque grains and aggregates, probably iron sulphides or oxides, are also present, and are especially abundant in the two thin sections from the Morella Fm in which sediments are known to have undergone oxidization processes owing to subaerial exposure during the earliest stages of diagenesis. Occasionally, they form irregular peloids (Fig. 2h)

\section{Magnetic mineralogies}

The 671 analysed standard samples show bulk magnetic susceptibility values between $1.66 \times 10^{-6}$ and $390.73 \times 10^{-6}$ SI when measured at room temperature. Of the results, $86 \%$ range between $50 \times 10^{-6}$ and $225 \times 10^{-6}$ SI (Fig. 3a). When considering values as an average per site (Table 1 ), results vary within a narrower range, from a minimum of $10.9 \times 10^{-6}$ SI at site JSA2 to a maximum of $245 \times 10^{-6} \mathrm{SI}$ at site MO1.

All the measured temperature-dependent magnetic susceptibility curves show concave-hyperbolic shapes in their initial part 

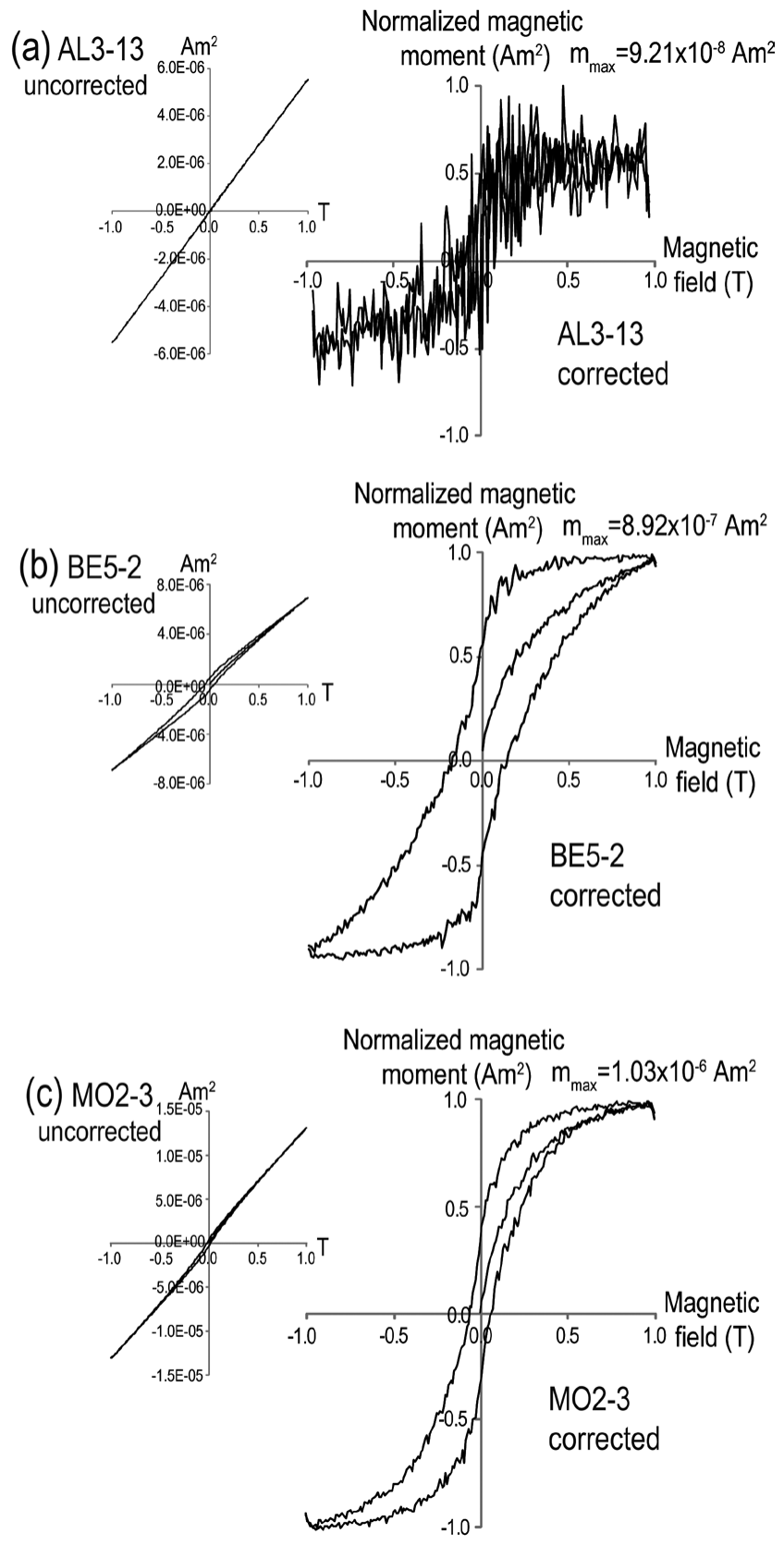

Fig. 4. Hysteresis loops of three representative samples: (a) linear shape typical of paramagnetic behaviour; $(\mathbf{b}, \mathbf{c})$ loops showing magnetic remanence, and thus confirming the presence of ferromagnetic phases. For the three cases, the paramagnetic effect is not corrected in the left graph, and is subtracted in the right graph.
(Fig. 3b-d), pointing to the presence of paramagnetic phases (phyllosilicates) in the samples. This shape is more evident in the results of low-temperature curves (Fig. $3 b$ and c). In some cases, curves show an abrupt increase in magnetic susceptibility from around $400^{\circ} \mathrm{C}$ to $500^{\circ} \mathrm{C}$ (Fig. $3 \mathrm{~b}$ and d). These behaviours indicate the new formation of ferromagnetic phases during the heating process and impede the reversibility of the cooling run with respect to the heating one. The newly formed ferromagnetic phase was generally magnetite (with a Curie temperature of $580^{\circ} \mathrm{C}$ ), which probably originated from the iron contained in other paramagnetic phases. In two out of the 13 cases, an original ferromagnetic content was also recorded by the heating curve. In these cases, a sharp susceptibility decay is observed at $680^{\circ} \mathrm{C}$ (i.e. Fig. 3d), which is the Néel temperature of hematite (Néel 1948).

The presence of a major paramagnetic fraction is also evidenced in the uncorrected results from 12 out of the 17 hysteresis loops (Fig. 4a), generally from sandstones, limestones and marly limestones. These cycles show high constant positive slopes, with the two halves of the loop superimposed. In addition, data become 'noisy' when applying the paramagnetic correction (Fig. 4a, right), supporting the negligible presence of ferromagnetic material (Tauxe 2008). However, the other five samples (all of them mudstones) show a typical ferromagnetic behaviour (Fig. 4b and c). All of them show 'wasp-waisted' shapes, characterized by a visible constriction of the loop in the part corresponding to the lowest applied fields. This shape can indicate the presence of a mixture of various ferromagnetic phases or the presence of different grain sizes of the same ferromagnetic mineral (Dunlop \& Özdemir 1997). Nonetheless, for the exact determination of the possible ferromagnetic minerals carrying part of the signal, further results are required.

A remarkable degree of noise is observed in 12 out of the 17 IRM acquisition curves and their backfield results (Fig. 5a). They coincide with the 12 samples with 'noisy' results from hysteresis loops. This behaviour confirms a low content of ferromagnetic phases in these samples. Most of them (10 out of the 12 cases) were completely saturated at $300 \mathrm{mT}$. Values for their magnetization saturation vary around $0.30 \times 10^{-8}$ and $1.40 \times 10^{-8} \mathrm{Am}^{2}$. In four of them the highly noisy data yielded incoherently high values of coercivity of remanence. The seven cases that do not reach a complete saturation at $1 T$ (Fig. $5 \mathrm{~b}$ and c) reflect the presence of highly coercive ferromagnetic phases with the highest values of coercivity of remanence, between 62 and $198 \mathrm{mT}$. Five samples of this group do not show noisy results (AL1-12, AL7-1, BE5-2, MO2-3 and MO3-11, all of them mudstones). The acquisition curves from the other two classified as 'noisy' (MO4-5 and MO14-9) yield the highest degree of saturation out of the seven undersaturated samples. It is noteworthy that these two sites are the only mudstones within the group of sites yielding noisy results.

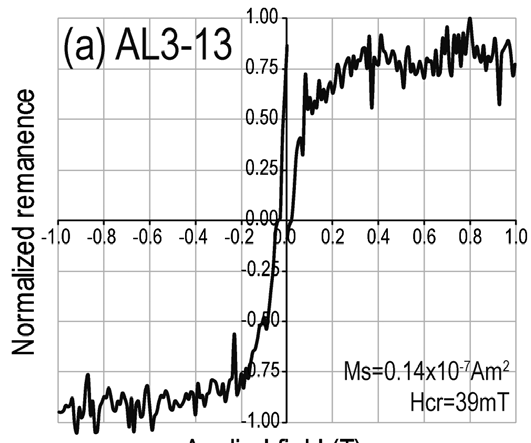

Applied field (T)

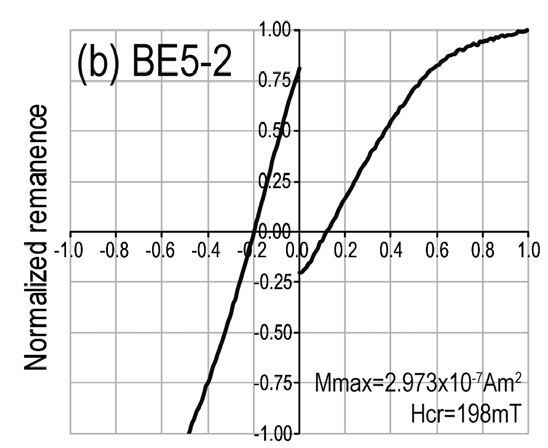

Applied field (T)

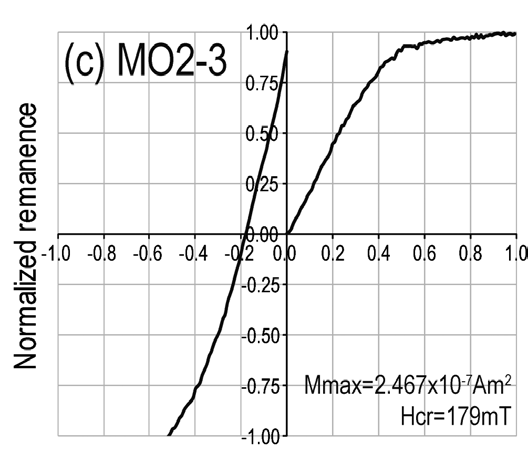

Applied field (T)

Fig. 5. IRM acquisition curves and backfield IRM of three representative samples: (a) saturated and noisy; (b) and (c) undersaturated at $1 T$ and well defined. 

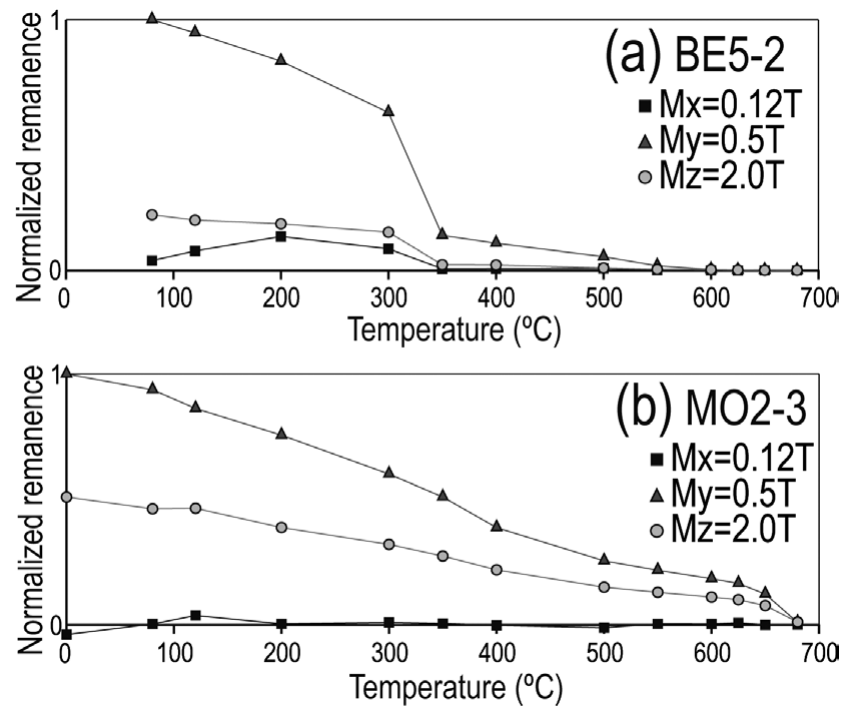

Fig. 6. Thermal demagnetization of composite IRM of two representative samples.

According to the previous results, the thermal demagnetization of a composite IRM was conducted on four of the samples that recorded magnetic remanence, and two behaviours were distinguished. Two samples show a certain degree of magnetization on the three axes, lower on the $x$ - and $z$-axes (120 and $2000 \mathrm{mT}$ ) and higher along the $y$-axis $(500 \mathrm{mT})$. There are abrupt breaks on the three axes around $325^{\circ} \mathrm{C}$, which could be due to the presence of an iron sulphide, probably pyrrhotite, as the magnetization carrier (Fig. 6a). The other two samples show negligible magnetization values along the $x$-axis and high magnetization values along the other two. An abrupt decay in remanent magnetization does not occur until around $675^{\circ} \mathrm{C}$, which is the unblocking temperature of hematite (Fig. 6b).

\section{AMS results}

Of the samples $90 \%$ show $P j$ values lower than 1.08 (Fig. 7a). The shape parameter $T$ generally varies within the oblate field, with $85 \%$ of the samples showing $T$ values higher than 0.3 (Fig. $7 b$ ). Negative $T$ values are returned by $7.7 \%$ of the samples, belonging mostly to sites JSA2, KXE1 and KXE2 (Table 1). The mean values of the magnetic anisotropy parameters are presented in Table 1 and Figure $7 \mathrm{c}-\mathrm{e}$. A slight positive tendency is observed when the anisotropy degree is plotted versus the bulk magnetic susceptibility values (Fig. 7c). High $T$ values generally dominate and the few negative values correspond to the lower $P j$ values (Fig. 7d) and to the lower bulk susceptibility values (Fig. 7e).

Average orientations per site from measuring LF-AMS at RT are presented in Table 2. At 36 out of the 42 sites, the $k_{\min }$ axes are oriented perpendicular or approximately perpendicular to the bedding plane (Fig. 8a, b.1, b.2, c and d.1). Results from Jelinek statistics show that the average orientation of the $k_{\min }$ axes differs more than $17^{\circ}$ from the orientation of the pole to bedding only at six sites (e.g. Fig. 8e). The largest deviation is around $52^{\circ}$ (Table 2) at site MO19 (see below). Regarding the confidence angles of the three main magnetic axes inferred from Jelinek results, three types of ellipsoids were differentiated (Table 2), as follows.

Type 1 (Fig. $8 \mathrm{a}-\mathrm{c}$ ). The 29 sites of this group are characterized by a remarkable degree of clustering of their minimum axes (confidence angles ranging between 6/4 and 20/5, Table 2). In 25 out of the 29 cases the $k_{\min }$ axes are perpendicular to the bedding plane. Thus, the magnetic foliation plane, which contains the $k_{\text {int }}$ and $k_{\max }$ axes, is parallel to bedding. Depending on the scattering degree of these two other axes, we differentiate three subgroups: 12 sites (type 1A) show magnetic lineations widely scattered within the magnetic foliation plane (Fig. 8a); 13 sites (type 1B) show the $k_{\max }$ and $k_{\text {int }}$ axes clustered within the magnetic foliation plane and a clear magnetic lineation is observed (Fig. 8b); the four remaining sites (type 1C) show the $k_{\max }$ axes clustered in two maxima, and
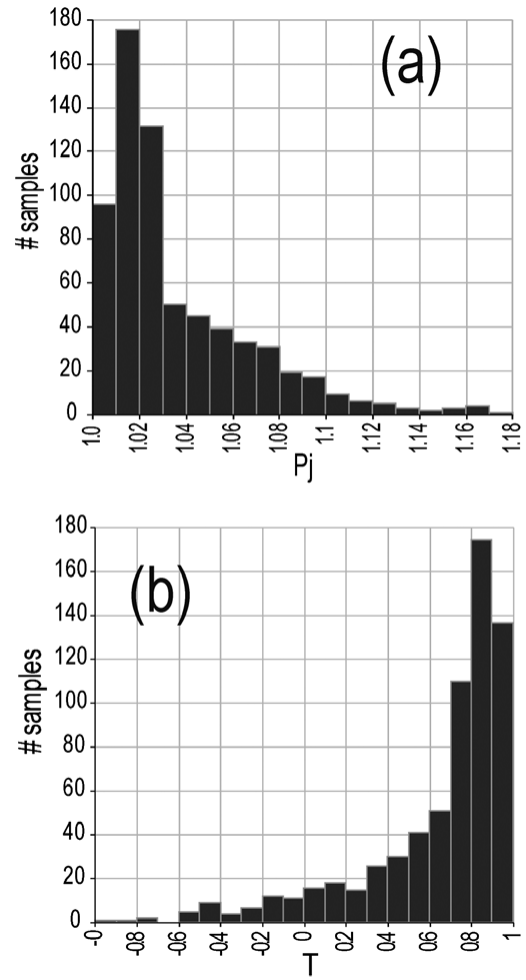
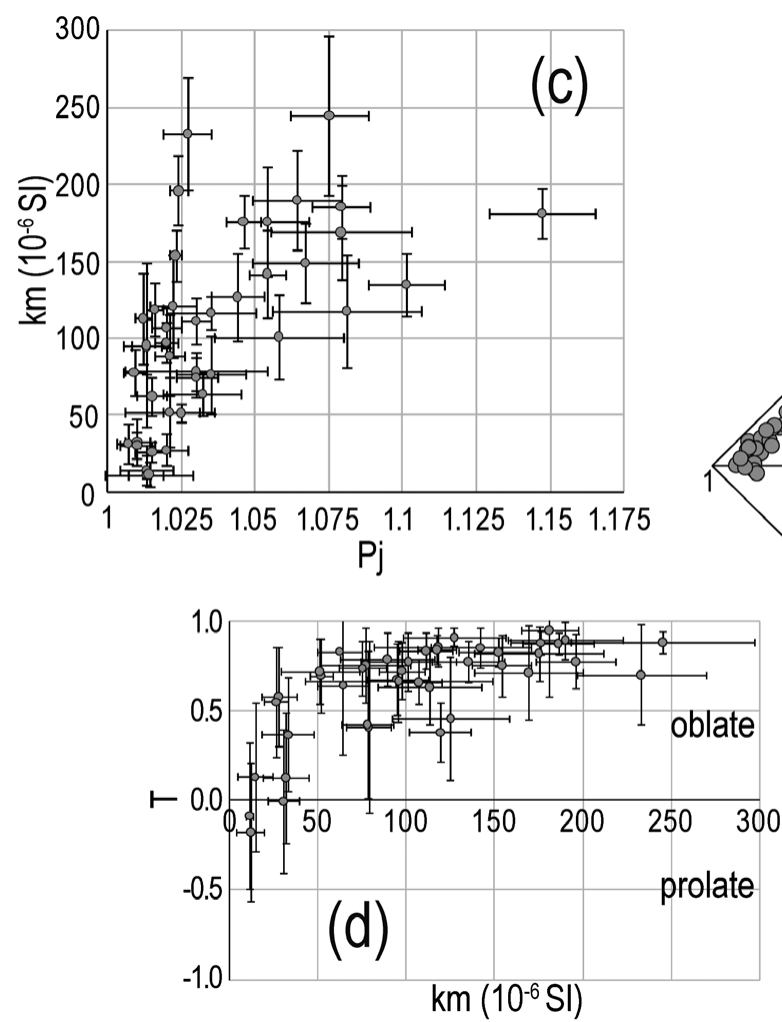

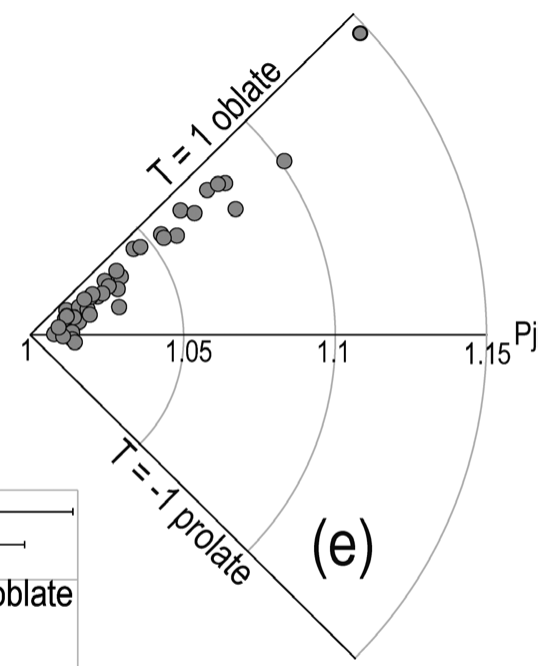

prolate

Fig. 7. Frequency histograms for (a) the corrected anisotropy degree $(P j)$ and (b) the shape parameter $(T)$ of all the samples included in the study. Graphs showing average sites of (c) $P j$ v. $\mathrm{km}$, and (d) $T$ v. $\mathrm{km}$, including error bars. (e) Polar plot of $T$ v. $P j$ (Borradaile \& Jackson 2004). 
Table 2. Summary of magnetic directional data

\begin{tabular}{|c|c|c|c|c|c|c|c|c|}
\hline Site & $k_{\max }(\mathrm{T} / \mathrm{P})$ & Conf. angle (deg.) & $k_{\text {int }}(\mathrm{T} / \mathrm{P})$ & Conf. angle (deg.) & $k_{\min }(\mathrm{T} / \mathrm{P})$ & Conf. angle (deg.) & Ellipsoid type & $S_{0}$ \\
\hline AL1 & $142 / 7$ & $32 / 8$ & $52 / 2$ & $32 / 6$ & $303 / 83$ & $9 / 8$ & $1 \mathrm{~B}$ & $085 / 13$ \\
\hline AL2 & $358 / 12$ & $60 / 15$ & $266 / 9$ & $60 / 28$ & $139 / 75$ & $29 / 11$ & 2 & $268 / 14$ \\
\hline AL3 & $336 / 8$ & $13 / 8$ & $68 / 16$ & $13 / 5$ & $221 / 72$ & $9 / 5$ & 1B & $287 / 22$ \\
\hline AL4 & $127 / 29$ & $35 / 11$ & $234 / 27$ & $36 / 33$ & $359 / 48$ & $34 / 11$ & 2 & $077 / 39$ \\
\hline AL5 & $10 / 18$ & $35 / 10$ & $270 / 27$ & $35 / 18$ & $130 / 57$ & $20 / 5$ & 1B & $215 / 29$ \\
\hline AL6 & $301 / 21$ & $21 / 4$ & $35 / 11$ & $21 / 5$ & $151 / 67$ & $11 / 4$ & 1B & $246 / 31$ \\
\hline AL7.1 & $131 / 8$ & $40 / 7$ & $40 / 2$ & $40 / 4$ & $299 / 82$ & $7 / 4$ & \multirow{2}{*}{$1 \mathrm{C}$} & \multirow{2}{*}{$052 / 11$} \\
\hline AL7.2 & $39 / 0$ & $13 / 5$ & $129 / 5$ & $15 / 12$ & $304 / 85$ & $15 / 5$ & & \\
\hline AL8 & $351 / 40$ & $14 / 6$ & $240 / 23$ & $16 / 11$ & $129 / 42$ & $14 / 5$ & 1B & $217 / 54$ \\
\hline BCE4 & $13 / 16$ & $60 / 26$ & $273 / 31$ & $60 / 30$ & $127 / 55$ & $30 / 26$ & 2 & $270 / 19$ \\
\hline BE1 & $194 / 4$ & $39 / 5$ & $284 / 3$ & $39 / 6$ & $50 / 85$ & $7 / 5$ & $1 \mathrm{~A}$ & $330 / 12$ \\
\hline BE2.1 & $201 / 3$ & $9 / 4$ & $112 / 5$ & $9 / 5$ & $318 / 84$ & $7 / 2$ & \multirow{2}{*}{$1 \mathrm{C}$} & \multirow{2}{*}{$304 / 07$} \\
\hline BE2.2 & $297 / 2$ & $67 / 10$ & $27 / 3$ & $67 / 4$ & $176 / 86$ & $11 / 3$ & & \\
\hline BE3 & $183 / 8$ & $61 / 9$ & $277 / 24$ & $61 / 7$ & $76 / 65$ & $10 / 6$ & $1 \mathrm{~A}$ & $116 / 11$ \\
\hline BE4 & $175 / 4$ & $24 / 3$ & $85 / 3$ & $24 / 13$ & $312 / 85$ & $13 / 3$ & $1 \mathrm{~A}$ & 065/09 \\
\hline BE5 & $147 / 16$ & $23 / 4$ & $50 / 21$ & $23 / 9$ & $272 / 63$ & $9 / 4$ & 1B & $009 / 28$ \\
\hline BE6 & $149 / 18$ & $25 / 13$ & $41 / 43$ & $80 / 20$ & $255 / 42$ & $80 / 16$ & 3 & $351 / 21$ \\
\hline BE7.1 & $138 / 5$ & $53 / 12$ & $229 / 5$ & $52 / 5$ & $3 / 84$ & $19 / 4$ & \multirow{2}{*}{$1 \mathrm{C}$} & \multirow{2}{*}{$058 / 06$} \\
\hline BE7.2 & $201 / 10$ & $25 / 4$ & $110 / 4$ & $25 / 8$ & $360 / 79$ & $9 / 2$ & & \\
\hline BE8 & $151 / 15$ & $26 / 7$ & $59 / 6$ & $26 / 16$ & $308 / 74$ & $17 / 6$ & 2 & $049 / 20$ \\
\hline BE9 & $161 / 4$ & $62 / 11$ & $71 / 3$ & $62 / 8$ & $309 / 85$ & $14 / 5$ & $1 \mathrm{~A}$ & $334 / 14$ \\
\hline JSA2 & $153 / 26$ & $50 / 18$ & $245 / 3$ & $50 / 20$ & $341 / 63$ & $20 / 20$ & 2 & $060 / 29$ \\
\hline JSA4 & $25 / 2$ & $21 / 4$ & $117 / 43$ & $21 / 12$ & $293 / 47$ & $13 / 4$ & 1B & $026 / 42$ \\
\hline KXE1 & $350 / 12$ & $36 / 16$ & $82 / 12$ & $31 / 14$ & $215 / 73$ & $35 / 21$ & 2 & $295 / 25$ \\
\hline KXE2 & $314 / 11$ & $59 / 24$ & $49 / 23$ & $60 / 37$ & $200 / 64$ & $38 / 23$ & 2 & $332 / 25$ \\
\hline KXE3 & $51 / 8$ & $41 / 16$ & $314 / 38$ & $42 / 21$ & $151 / 51$ & $24 / 15$ & 2 & $235 / 30$ \\
\hline MO1 & $149 / 0$ & $26 / 6$ & $59 / 12$ & $27 / 14$ & $241 / 78$ & $17 / 5$ & $1 \mathrm{~B}$ & $250 / 05$ \\
\hline $\mathrm{MO} 2$ & $323 / 5$ & $60 / 8$ & $232 / 3$ & $60 / 8$ & $115 / 84$ & $10 / 5$ & $1 \mathrm{~A}$ & $000 / 00$ \\
\hline MO3 & $205 / 1$ & $23 / 7$ & $295 / 7$ & $24 / 14$ & $110 / 83$ & $14 / 7$ & $1 \mathrm{~B}$ & $190 / 11$ \\
\hline MO4 & $159 / 2$ & $30 / 6$ & $69 / 2$ & $30 / 11$ & $294 / 88$ & $11 / 6$ & $1 \mathrm{~A}$ & $040 / 05$ \\
\hline MO5B & $293 / 3$ & $70 / 14$ & $23 / 14$ & $70 / 28$ & $191 / 76$ & $28 / 14$ & 2 & $303 / 07$ \\
\hline MO6.1 & $355 / 3$ & $57 / 14$ & $265 / 0$ & $57 / 8$ & $168 / 87$ & $17 / 5$ & \multirow{2}{*}{$1 \mathrm{C}$} & \multirow{2}{*}{$300 / 14$} \\
\hline MO6.2 & $49 / 2$ & $29 / 5$ & $319 / 1$ & $29 / 9$ & $205 / 88$ & $11 / 4$ & & \\
\hline MO7 & $31 / 5$ & $38 / 8$ & $122 / 10$ & $37 / 24$ & $275 / 79$ & $25 / 11$ & 2 & $000 / 00$ \\
\hline MO8 & $17 / 7$ & $42 / 12$ & $107 / 3$ & $42 / 18$ & $224 / 83$ & $19 / 12$ & 2 & $267 / 06$ \\
\hline MO9 & $263 / 7$ & $66 / 9$ & $354 / 6$ & $66 / 11$ & $127 / 81$ & $11 / 10$ & $1 \mathrm{~A}$ & $341 / 15$ \\
\hline MO10 & $252 / 3$ & $42 / 8$ & $342 / 8$ & $42 / 13$ & $143 / 81$ & $13 / 8$ & $1 \mathrm{~A}$ & $296 / 12$ \\
\hline MO11 & $317 / 9$ & $59 / 4$ & $49 / 10$ & $59 / 5$ & $185 / 77$ & $6 / 4$ & $1 \mathrm{~A}$ & $299 / 14$ \\
\hline MO12 & $241 / 0$ & $40 / 3$ & $151 / 0$ & $40 / 8$ & $12 / 89$ & $8 / 3$ & $1 \mathrm{~A}$ & $261 / 09$ \\
\hline MO13 & $258 / 0$ & $35 / 3$ & $349 / 6$ & $35 / 8$ & $265 / 84$ & $9 / 3$ & $1 \mathrm{~A}$ & $222 / 12$ \\
\hline MO14 & $225 / 2$ & $14 / 6$ & $315 / 2$ & $14 / 8$ & $89 / 88$ & $8 / 6$ & $1 \mathrm{~B}$ & $198 / 06$ \\
\hline MO15 & $144 / 32$ & $32 / 4$ & $46 / 11$ & $31 / 10$ & $229 / 56$ & $11 / 10$ & $1 \mathrm{~B}$ & $024 / 38$ \\
\hline MO16 & $42 / 2$ & $24 / 4$ & $133 / 7$ & $24 / 7$ & $296 / 83$ & $8 / 3$ & 1B & $025 / 06$ \\
\hline MO17 & $331 / 5$ & $19 / 6$ & $62 / 3$ & $20 / 12$ & $184 / 84$ & $12 / 7$ & $1 \mathrm{~B}$ & $271 / 19$ \\
\hline MO18 & $61 / 5$ & $50 / 7$ & $330 / 14$ & $50 / 4$ & $170 / 75$ & $8 / 2$ & $1 \mathrm{~A}$ & $250 / 18$ \\
\hline MO19 & $346 / 34$ & $17 / 7$ & $220 / 41$ & $28 / 15$ & $100 / 30$ & $28 / 8$ & 3 & $352 / 71$ \\
\hline
\end{tabular}

In situ values for $k_{\max }, k_{\text {int }}$ and $k_{\min }$ mean orientations (T/P, trend/plunge) from the 55 sites of the study. Conf. angle, confidence angle (error angle around the average axes), based on Jelinek statistics and calculated with Anisoft42 (Chadima \& Jelinek 2009). $S_{0}$, strike and dip of bedding planes following the right-hand-rule system.

thus, two main magnetic lineation orientations per site can be inferred (Fig. 8c).

Type 2 (Fig. 8d). This group includes 11 sites characterized by a poor clustering of their three magnetic axes (Fig. 8d.1). Some of them seem to show an incipient distribution of the $k_{\min }$ and $k_{\text {int }}$ axes interchanged within a girdle (Fig. 8d.2).

Type 3 (Fig. 8e). Only two sites are included in this group. BE6 presents the $k_{\max }$ axes clustered near the magnetic foliation plane and the $k_{\min }$ and the $k_{\text {int }}$ axes plot along a girdle (Fig. 8e). MO19 shows a strong obliquity between the magnetic foliation and the bedding plane (see below).

When considering mean orientations of the magnetic lineation and their confidence angles (Table 2, Fig. 9), we observe that 18 sites show magnetic lineation oriented from NW-SE (11 sites, Fig. 8a.1, b.1, d.2 and e) to NNW-SSE (seven sites, Fig. 8b.3). Half of these cases belong to types $1 \mathrm{~A}$ and 2 and thus show a high dispersion of the $k_{\max }$ axes. Another group of 15 sites yields magnetic lineations oriented NE-SW (six sites, Fig. 8a.2, b.2 and d.1), NNE-SSW (seven sites), and ENE-WSW (two sites). Nine of them belong to types $1 \mathrm{~A}$ and 2. A smaller group of four sites show magnetic lineation oriented mainly north-south, and all of them are classified as types 1A (Fig. 8a.3) and 2. Site MO9 (type 1A) shows a highly scattered magnetic lineation oriented around eastwest. Sites of type $1 \mathrm{C}$ show two principal magnetic lineations per site (Fig. 8c.1). All four have a maximum oriented NW-SE. Three of them have a secondary one oriented NE-SW, and one (site BE7) has its second maximum oriented around north-south. When plotting the 42 magnetic lineations on a geological map of the region (Fig. 9), we can observe two domains of magnetic lineation orientations: in the northern and western parts of the studied region, 

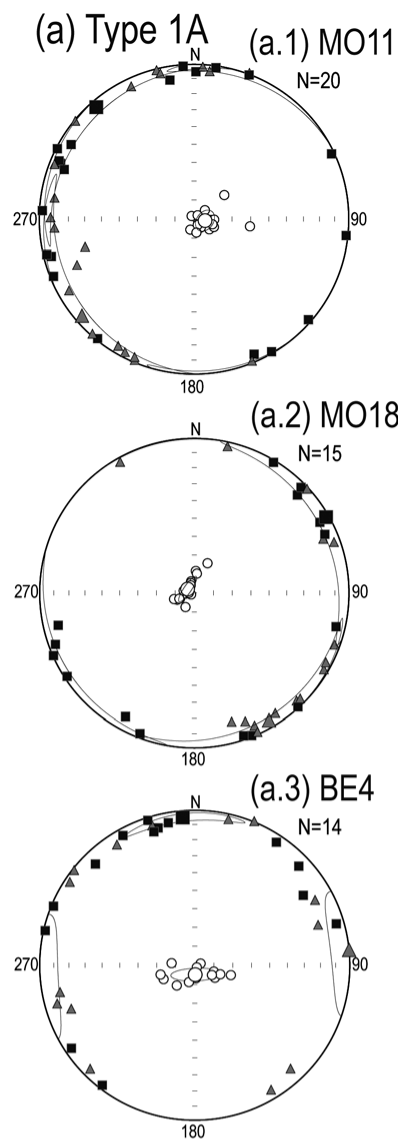

(b) Type 1B
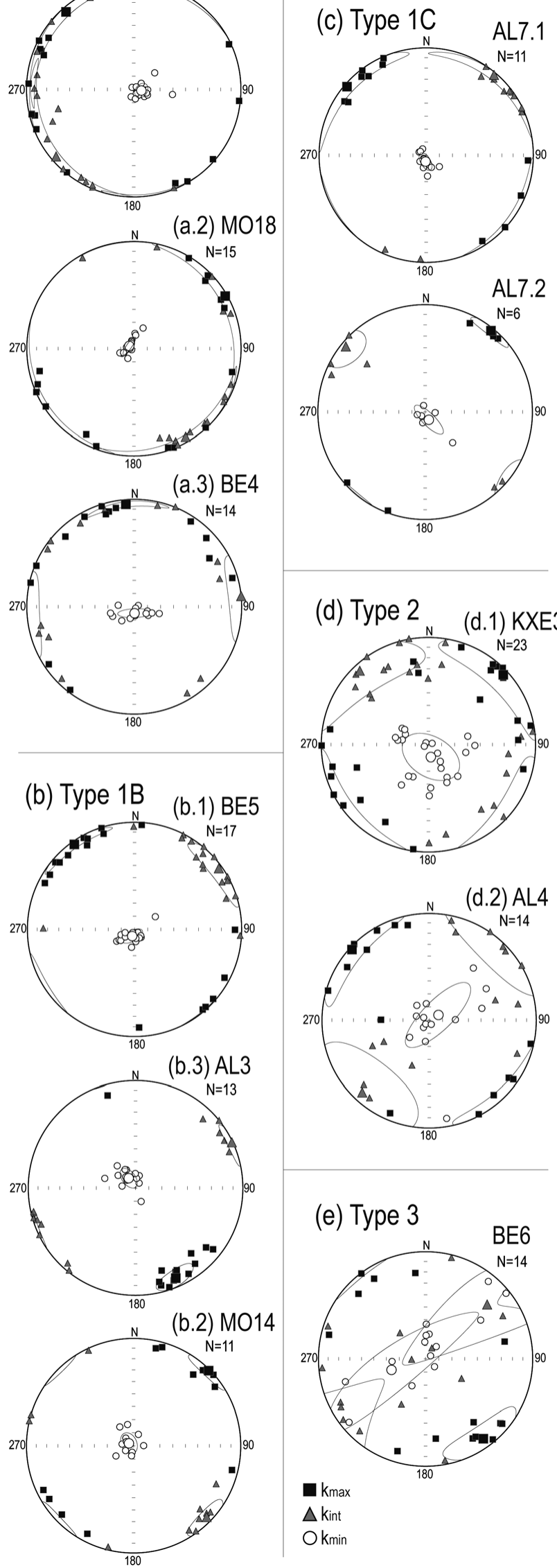

(d) Type 2
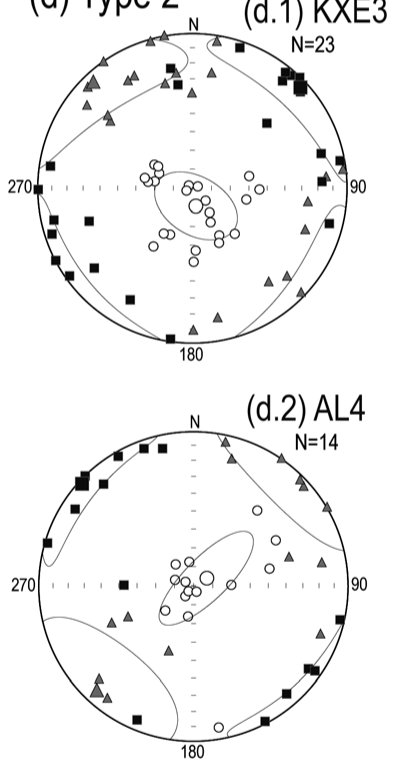

(e) Type 3

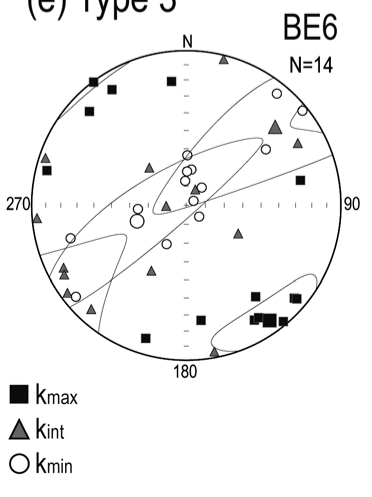

Fig. 8. Equal area projection of the three magnetic axes, after restoring bedding to horizontal, of representative sites of the types of ellipsoids described in the text: (a) Type 1A; (b) Type 1B; (c) Type 1C; (d) Type 2 ; (e) Type 3 . Squares, $k_{\max }$; triangles, $k_{\text {int }}$; circles, $k_{\min }$. sites showing approximate orientations NNE-SSW and NE-SW for their magnetic lineations dominate; in the southeastern area, sites with magnetic lineations orientations around NW-SE and WNW-ESE dominate. Exceptions within these domains will be discussed in the following sections.

Low-temperature AMS data from 42 samples distributed over seven sites are summarized in Table 3. Ratios of LT with respect to RT bulk susceptibilities vary from 1.98 to 2.88 . Although these values are lower than the expected 3.8 for a unique and purely paramagnetic phase, the considerable increase of bulk susceptibilities at low temperature demonstrates a predominant presence of paramagnetic minerals (e.g. Lüneburg et al. 1999). When we compare ellipsoid orientations from both techniques (Fig. 10), we observe that the mean orientation of the three magnetic axes remains similar in both cases (at RT and LT). The only differences found between the two sets of results are related to the degree of clustering of the magnetic axes in some cases (Table 3 ). In particular, four out of the seven sites show a higher clustering of the three magnetic axes at LT (Fig. 10a and b). Two other sites show magnetic axes slightly more scattered at LT than at RT (Fig. 10c). Only site MO3 (Fig. 10d) shows similar values for the confidence angles of its magnetic axes at RT and LT.

\section{Discussion}

\section{Magnetic mineralogy}

Results from the rock magnetism techniques point to a prevalence of paramagnetic minerals (e.g. phyllosilicates) in the studied samples (Fig. 3). Large contributions of ferromagnetic sensu lato phases are decisively discarded in most cases (e.g. Figs 4a and 5a). Only five out of the 17 samples from rock magnetism analyses show magnetic remanence, carried by medium and mostly highly coercive ferromagnetic minerals. According to their unblocking temperatures, iron sulphides and hematite are present at different sites (Fig. 6). The presence of magnetite is definitely discarded.

To determine if magnetic carriers influence differently the orientation of the AMS ellipsoids, we applied a subfabrics separation method. The AMS at LT helps evaluate the effect of the paramagnetic fraction. The increase of the bulk susceptibility values at LT indicates the prevalence of paramagnetic minerals, such as phyllosilicates, as main carriers of the AMS. At the same time, the orientation of the magnetic ellipsoids at LT is equivalent to the ellipsoids at RT in all measured cases. This fact confirms that, in general, all magnetic phases share the same magnetic fabric. The parallel disposition of opaque grains and phyllosilicate flakes observed in thin sections (e.g. Fig. 2e) also suggests that they carry the same magnetic fabric.

\section{Magnetic fabric origin}

A slight correlation was found between $P j$ and $\mathrm{km}$ (Fig. 7c) and between $P j$ and $T$ (Fig. 7d). An interpretation given in the literature to explain this correlation is the influence of the magnetic mineralogy on the mineral arrangement (Rochette 1987; Rochette et al. 1992; Hrouda \& Jelinek 1990). Another reason can be found when linking it with strain (e.g. Borradaile \& Henry 1997; Robion et al. 2007). Relatively low $P j$ values are found in our samples and the highest of these $P j$ values are associated with highest $T$ values (i.e. oblate geometries). According to the above-mentioned previous models, our results seem to indicate a sedimentary origin for the magnetic fabric.

Petrographic observations of the studied rocks show that in cases in which a sedimentary lamination is observed, phyllosilicate and iron oxide grains remain parallel to the sedimentary laminae. In addition, most of the considered magnetic fabrics (Types 1 and 2; i.e. 40 sites out of the 42 studied cases) show 


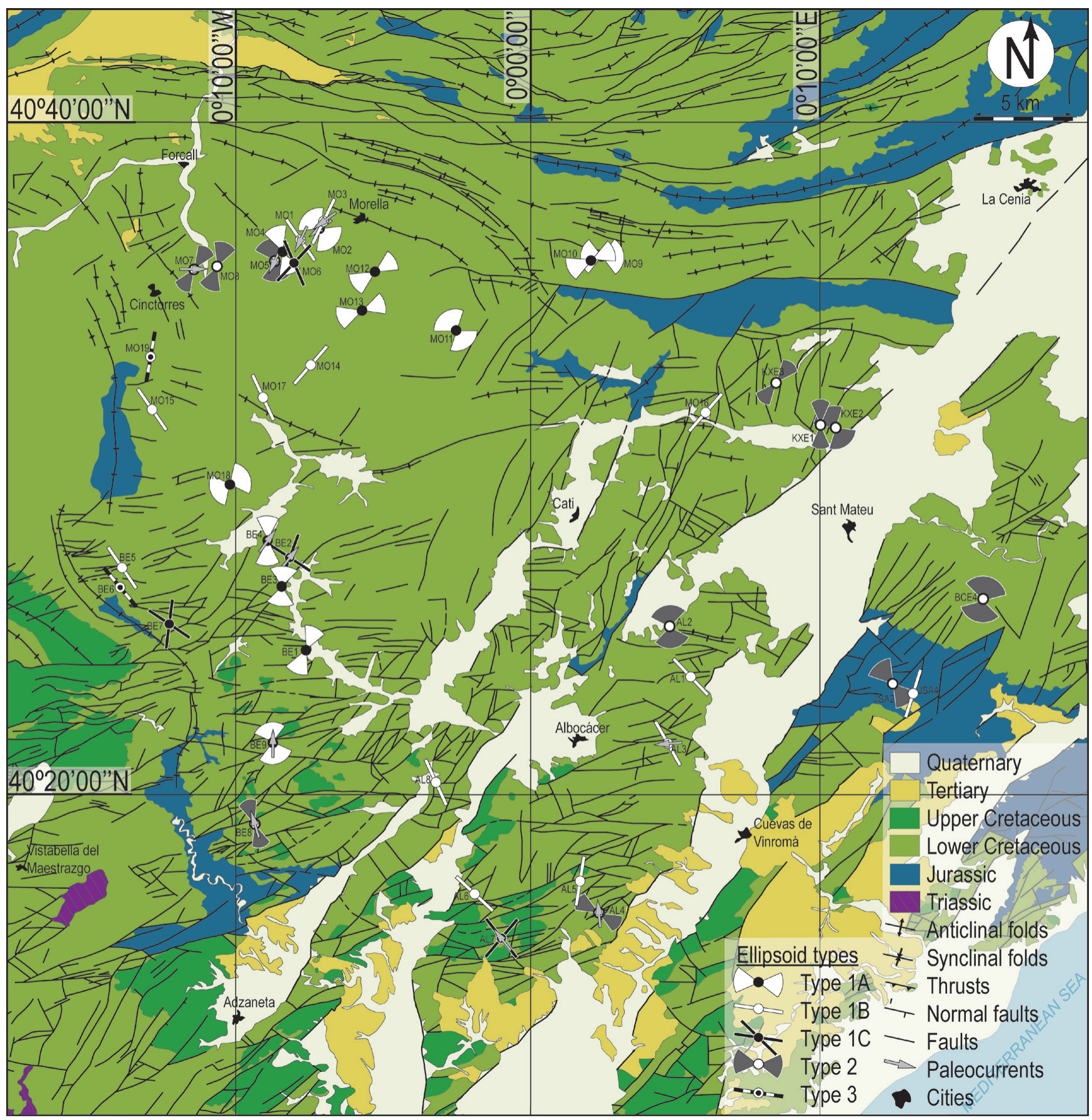

Fig. 9. Detailed geological map of the study area modified from Simón et al. (2012) and GEODE (2013). Magnetic lineations per site, spatially oriented after restoring bedding to horizontal, are superimposed on the geological map. Lines represent sites with a clearly developed magnetic lineation, whereas two symmetric circular sectors represent lineation at sites with a high scatter of $k_{\max }$. The angle of the circular sectors approximately corresponds to the confidence angle given by Jelinek statistics for each site. The ellipsoid types described in the text are represented by different symbols as listed in the legend. Grey arrows represent palaeocurrent directions where cross-bedding was observed.

magnetic foliation planes parallel or nearly parallel to the bedding plane at each site. This geometry also suggests the influence of sedimentary compactional processes.

Magnetic lineations are generally well developed within the magnetic foliation plane. Considering that our magnetic fabrics developed at an early stage, the clustering of the $k_{\max }$ axes has to be linked either to the effect of sedimentary features able to imprint an orientation on the magnetic fabric, or to the effect of the strain owing to the tectonic regime acting during sedimentation and early diagenesis (in our case, extensional processes).

Orientation of cross-bedding was measured in 12 outcrops out of the 42 studied sites within layers located below or above the sam- pled ones. These layers are composed of larger grain-size lithologies and are generally more competent than the studied lithologies. Palaeocurrent orientations according to these structures show a large variability independently of their stratigraphic position (Fig. 9). Magnetic lineations at the 12 sites near the layers where crossbedding was shown also show variable orientations, being parallel to the palaeocurrent direction in only five cases. When dealing with lithologies consisting of clay-sized particles, the mechanism known to control deposition is flocculation. This mechanism dominates in environments where currents lose their energy, allowing also siltsized grains to deposit. In these sediments, palaeocurrent imprint is extremely minimized. Therefore, and after evaluating the orienta- 
Table 3. Summary of bulk susceptibility data and magnetic directional data from specimens measured both at room and at low temperature

\begin{tabular}{|c|c|c|c|c|c|c|c|c|c|}
\hline Site & $k m\left(\times 10^{-6}\right)$ & $e\left(\times 10^{-6}\right)$ & $\mathrm{LT} / \mathrm{RT}$ & $k_{\max }(\mathrm{T} / \mathrm{P})$ & $\begin{array}{l}\text { Conf. angle } \\
\text { (deg.) }\end{array}$ & $k_{\text {int }}(\mathrm{T} / \mathrm{P})$ & $\begin{array}{l}\text { Conf. angle } \\
\text { (deg.) }\end{array}$ & $k_{\min }(\mathrm{T} / \mathrm{P})$ & $\begin{array}{l}\text { Conf. angle } \\
\text { (deg.) }\end{array}$ \\
\hline AL2 LT & 67.9 & 4.71 & \multirow{2}{*}{1.98} & $145 / 5$ & $19 / 4$ & $55 / 7$ & $15 / 4$ & $270 / 82$ & $21 / 12$ \\
\hline AL2 RT & 34.3 & 16.5 & & $311 / 4$ & $21 / 8$ & $42 / 4$ & $18 / 11$ & $174 / 85$ & $19 / 17$ \\
\hline AL4 LT & 69.3 & 12.7 & \multirow{2}{*}{2.37} & $146 / 30$ & $19 / 6$ & $243 / 11$ & $16 / 4$ & $351 / 58$ & $13 / 4$ \\
\hline AL4 RT & 29.2 & 14 & & $129 / 29$ & $22 / 7$ & $241 / 33$ & $42 / 20$ & $8 / 43$ & $42 / 8$ \\
\hline BE1 LT & 167 & 13.1 & \multirow{2}{*}{2.36} & $144 / 1$ & $18 / 8$ & $234 / 5$ & $18 / 2$ & $48 / 85$ & $8 / 2$ \\
\hline BE1 RT & 70.8 & 12 & & $167 / 2$ & $43 / 5$ & $257 / 4$ & $43 / 3$ & $46 / 86$ & $9 / 2$ \\
\hline BE6 LT & 191 & 15.5 & \multirow{2}{*}{2.30} & $145 / 17$ & $18 / 9$ & $48 / 22$ & $24 / 13$ & $268 / 62$ & $21 / 10$ \\
\hline BE6 RT & 83.2 & 14.8 & & $135 / 19$ & $9 / 4$ & $45 / 1$ & $57 / 5$ & $313 / 71$ & $57 / 8$ \\
\hline MO3 LT & 534 & 35.8 & \multirow{2}{*}{2.34} & $212 / 3$ & $29 / 5$ & $303 / 12$ & $32 / 7$ & $107 / 77$ & $20 / 4$ \\
\hline MO3 RT & 228 & 18.2 & & $208 / 4$ & $29 / 6$ & $299 / 13$ & $31 / 19$ & $103 / 77$ & $23 / 5$ \\
\hline MO6 LT & 602 & 21.7 & \multirow{2}{*}{2.88} & $23 / 6$ & $58 / 10$ & $113 / 5$ & $58 / 9$ & $245 / 83$ & $14 / 1$ \\
\hline MO6 RT & 209 & 12.1 & & $29 / 4$ & $33 / 7$ & $119 / 0$ & $33 / 12$ & $213 / 86$ & $15 / 3$ \\
\hline MO11 LT & 170 & 9.32 & \multirow{2}{*}{2.78} & $336 / 13$ & $48 / 4$ & $68 / 8$ & $48 / 8$ & $188 / 75$ & $9 / 4$ \\
\hline MO11 RT & 61.2 & 14.1 & & $333 / 10$ & $11 / 5$ & $64 / 7$ & $12 / 6$ & $189 / 78$ & $10 / 4$ \\
\hline
\end{tabular}

LT, low temperature; RT, room temperature; $k m$, bulk susceptibility (in SI units); $e$, standard deviation of $k m$; LT/RT, ratio comparing $k m$ values at LT and RT; in situ values for $k_{\max }, k_{\text {int }}$ and $k_{\min }$ mean orientations (T/P, trend/plunge); Conf. angle, confidence angle (error angle around the average axes), based on Jelinek statistics and calculated with Anisoft42 (Chadima \& Jelinek 2009). $S_{0}$, Strike and dip of the bedding planes following the right-hand-rule system.
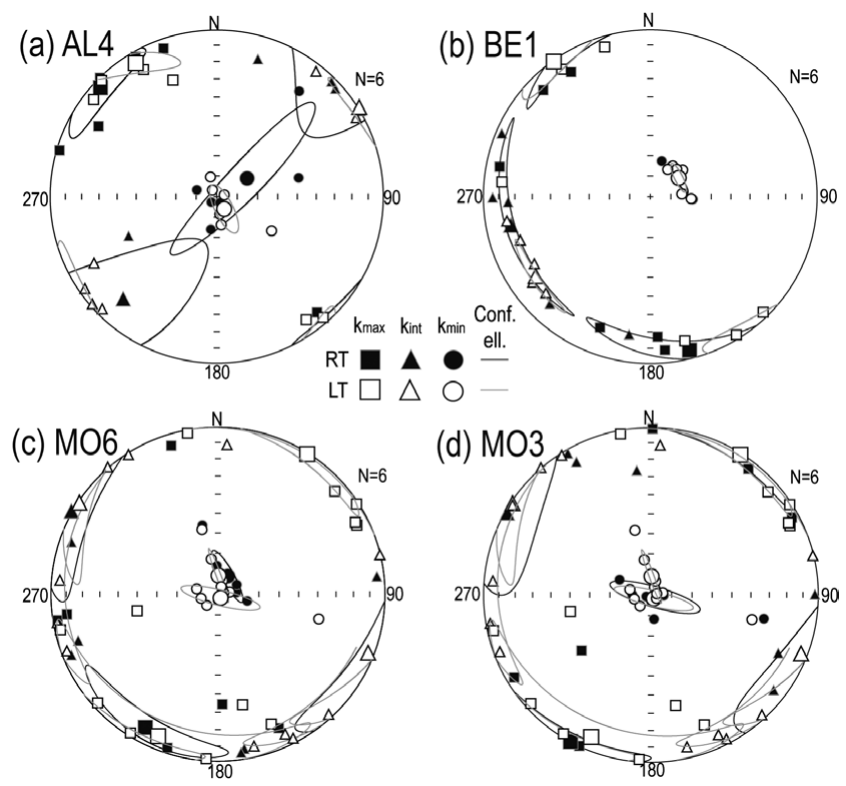

Fig. 10. Equal area projection of the three magnetic axes (squares, $k_{\max }$; triangles, $k_{\text {int }}$; circles, $k_{\min }$ ), after restoring bedding to horizontal, of low-field AMS at room temperature (black symbols) and low-field AMS at low temperature (white symbols) from four representative sites. Conf. ell.: confidence ellipses.

tions of the observed palaeocurrents, we deduce that the palaeocurrents are not influencing the orientations of magnetic lineation in the rocks from the sampled layers.

One of the most notable factors that can reorient magnetic fabrics is the sequential superimposition of tectonic regimes. In extensional contexts, magnetic lineation is parallel to the extension direction (i.e. perpendicular to normal faults; e.g. Mattei et al. 1997; Cifelli et al. 2005). Conversely, in compressive settings, it is oriented perpendicular to the shortening direction (i.e. parallel to the strike of thrusts; e.g. Borradaile \& Jackson 2004; Parés et al. 1999). In the studied region, it is necessary to identify the influence of the Cenozoic compression on the primary magnetic fabric that is supposed to record the synextensional stage.

The Cenozoic deformation in the central areas of the Maestrat basin is characterized by fault reactivation and the development of joint systems (Liesa 2000; Liesa et al. 2004; Antolín-Tomás et al. 2007). Compressive structures are widespread in the northern basin border, which is the area between the Iberian Range and the Catalonian Coastal Range, the so-called Linking Zone (Salas et al. 2001), and define a thin-skinned fold and thrust system. Furthermore, towards the west, several anticlines with an approximate north-south trend can be found (Fig. 9). Some of these anticlines located in marginal areas of the basin show axial-plane cleavage in some rock types (Liesa et al. 2004). Conversely, penetrative structures are completely absent in the basin centre throughout the Cretaceous series (e.g. Liesa et al. 1996; Liesa 2000). Thin-section description corroborates these observations, because no compressional-related structures were observed at microscale and, on the contrary, the original sedimentary lamination is clearly defined in most samples (e.g. Fig. 2e-h).

Geometries of magnetic ellipsoids fit generally with a sedimentary origin, with their $k_{\min }$ axes oriented around the pole to bedding. However, geometries found at the two sites forming Type 3 of our classification strongly differ from the rest. Site BE6 shows an incipient girdle between the $k_{\min }$ and $k_{\text {int }}$ axes, typical of magnetic fabrics influenced by compressional processes. In addition, it is located close to a NW-SE-trending fold in the western limit of the study area (Fig. 9). Its magnetic lineation orientation, NW-SE, is parallel to the fold trend in this area, and thus probably is compression-related. Therefore, for this site, together with the neighbouring sites BE5 and BE7, magnetic fabrics are interpreted as modified by the compressional stage (see discussion below). This interpretation agrees with previous results in the Cabuérniga basin (Oliva-Urcia et al. 2013), where even in absence of clear structural markers of compressional deformation (no cleavage is present), a 'modified extensional magnetic fabric' can be interpreted between extensional (inherited from the extensional stage) and compressional (clearly defined when cleavage is present and resulting from the modification during inversion) magnetic fabrics. Northwards of BE5, BE6 and BE7, the two sites located in the eastern flank of the Bobalar anticline (MO15 and MO19) do not show a girdle containing $k_{\text {int }}$ and $k_{\min }$, but their magnetic lineations are oriented approximately parallel to the fold trend. In MO19, also included in Type 3 , magnetic foliation deviates around $52^{\circ}$ from the bedding plane. In addition, tectonic foliation has been recognized in a level of marls situated several metres below the sampled layers (Fig. 11a). The orientation of this penetrative structure is parallel to the orientation of the magnetic lineation, and both are consistent with 


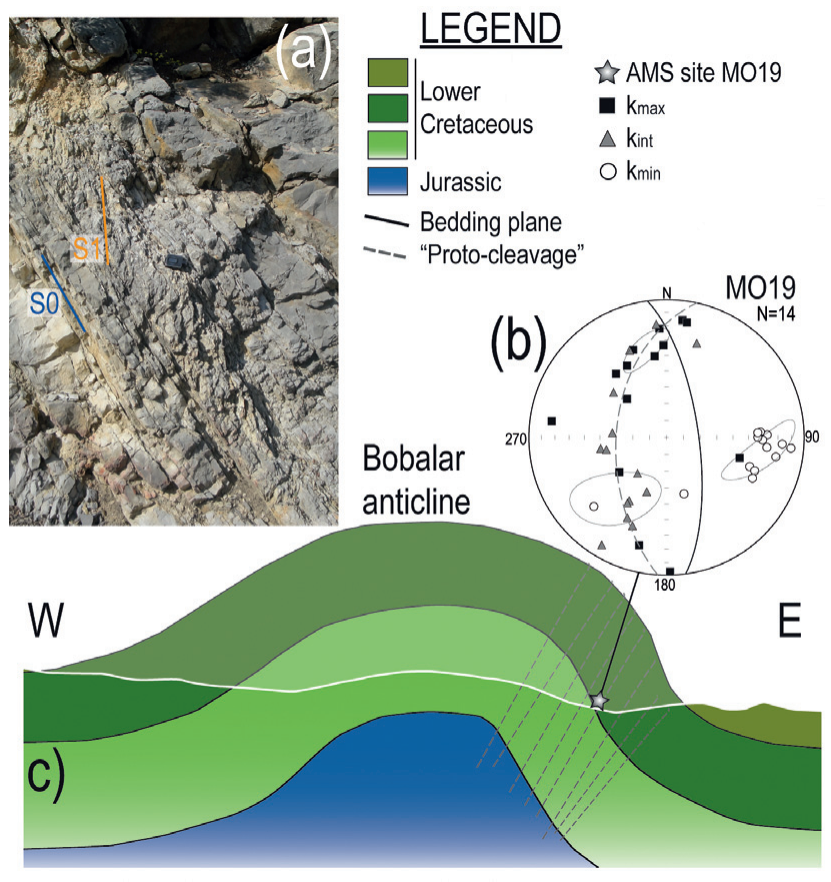

Fig. 11. Site MO19. (a) Cleavage observed in stratigraphic layers situated below the sampled ones. (b) AMS results of the site before bedding correction, together with (c) its position within a geological cross-section of the Bobalar anticline. Dashed grey lines (in the crosssection and in the stereographic projection) represent the magnetic foliation plane and a parallel 'proto-cleavage' interpreted to have reoriented the magnetic fabric.

the eastern flank of the fold and point to magnetic fabrics modified by compression (Fig. 11b). Sites MO9 and MO10 were also included in this group of compressional-driven magnetic fabrics. They are near the northern border of the Maestrat basin and relatively close to the strongly folded area in the Linking Zone (Fig. 9), and show $k_{\max }$ axes roughly parallel to the trends of compressional structures.

According to the criteria and caveats described above, we interpret the magnetic ellipsoids of the remaining sites ( $84 \%$ of the analysed sites) as inherited from the sedimentary stage and influenced by the Mesozoic extension in the Maestrat basin.

\section{The Mesozoic extension in the Maestrat basin according to $A M S$ results}

Two main tectonic-scale processes coexisted during the Early Cretaceous and influenced the evolution of the Iberian plate: the opening of the Tethys Ocean to the SE and the opening of the Bay of Biscay to the NW. The Maestrat basin was influenced by both events, because of its geographical location in the convergence between the two extensional domains (Álvaro et al. 1979; Salas \& Casas 1993). At the regional scale, this situation turned into an almost radial extensional stress field (e.g. Álvaro et al. 1979; Liesa et al. 2004; Antolín-Tomás et al. 2007). The reactivation of some sets of fractures during the Cenozoic compression and the Neogene extensional stage could also limit the use of fault trends to establish a zonation between the effects from both Mesozoic extensional processes. Within the observed radiality, a slight predominance of two extension directions has been described in two domains, coastward and inward (e.g. Aranda \& Simón 1993; Rodríguez-López et al. 2006). In the inner domain, the extension direction is NE-SW to NNE-SSW and coincides with that described for the second Mesozoic rifting stage in the Iberian basin. It is linked to the opening of the Bay of Biscay and the basin stage in the Pyrenean area, and triggered the development of the Early Cretaceous system of strongly subsiding basins throughout the Iberian basin. The domain identified towards the coastline shows a main NW-SE extension direction and is related to the influence of the Tethyan western margin configuration process during the Early Cretaceous.

The orientation of the magnetic fabrics interpreted as extensionrelated in our study fits in general with these two domains with different extension directions. A major part of the sites located inwards in the northwestern part of the Maestrat basin have magnetic lineations oriented approximately NNE-SSW and NE-SW (Fig. 12b). These directions are parallel to the extension directions related to the Iberian Mesozoic rifting and allow us to delimit what we have named the Iberian domain (Fig. 12a). Sites located in the southeastern part of the sampled area generally show magnetic lineations oriented around NW-SE and NNW-SSE (Fig. 12c), which approximately coincides with the extension direction described for the Tethys opening process. Their spatial arrangement allows us to demarcate the domain called hereafter the Tethyan domain towards the present coastline (Fig. 12a).

Apart from the exceptions already determined as clearly influenced by Cenozoic compression, some sites show magnetic lineation orientations different from those expected in the domain within which they are located. For the Tethyan domain, anomalous orientations in the magnetic lineation are scarce. When present, they show a NNE-SSW direction, which fits with that expected for the Iberian domain. In contrast, anomalous orientations are more common in the Iberian domain and show orientations related to the Tethys opening. Moreover, the small group of sites classified as Type 1C show two main orientations of magnetic lineation at the same site (Fig. 8c). Most of these cases could be interpreted as the result of the influence of both extensional processes, even at outcrop scale. They could also be interpreted as the effect of chronological changes in the dominant tectonic processes, which would cause interactions between the two domains through time. Changes in the orientation of the extension regime during the Early Cretaceous have been recognized for the western sector of the Iberian Range (Soto et al. 2008). In the studied sediments, when comparing magnetic fabric results and position within the stratigraphic profile, a relationship between the orientation of magnetic lineations and age is not observed. Thus, these anomalous orientations probably demonstrate that the limits between the two domains were not strictly fixed. When considering the whole area of the Maestrat basin as the junction of two tectonic domains (e.g. Álvaro et al. 1979) it is understandable that structures influenced by two approximately perpendicular extension directions developed throughout the rifting period in the Maestrat basin or even acted at the same time. The key point highlighted by this study is that, in spite of this mixture in the distribution of structure orientations, the change from one tectonic domain to the other can be roughly identified by means of AMS.

\section{Conclusions}

Rock magnetism analyses carried out in the Lower Cretaceous synrift units of the Maestrat basin indicate that phyllosilicates are the main carriers of the magnetic fabric. Sometimes they are accompanied by a small fraction of ferromagnetic minerals, consisting of hematite or iron sulphides (probably pyrrhotite). All these magnetic contributors share the orientation of their magnetic fabrics, which can be accordingly interpreted to share the same origin. Palaeocurrents have been detected in less than a quarter of the studied outcrops, and never within the sampled beds. Their dispersion and different directions indicate that they do not have a significant influence on the orientation of the magnetic lineations.

Most of the AMS sites are interpreted to maintain the original synsedimentary fabric orientation, which was conditioned by the extensional regime acting during the deposition of the Lower 


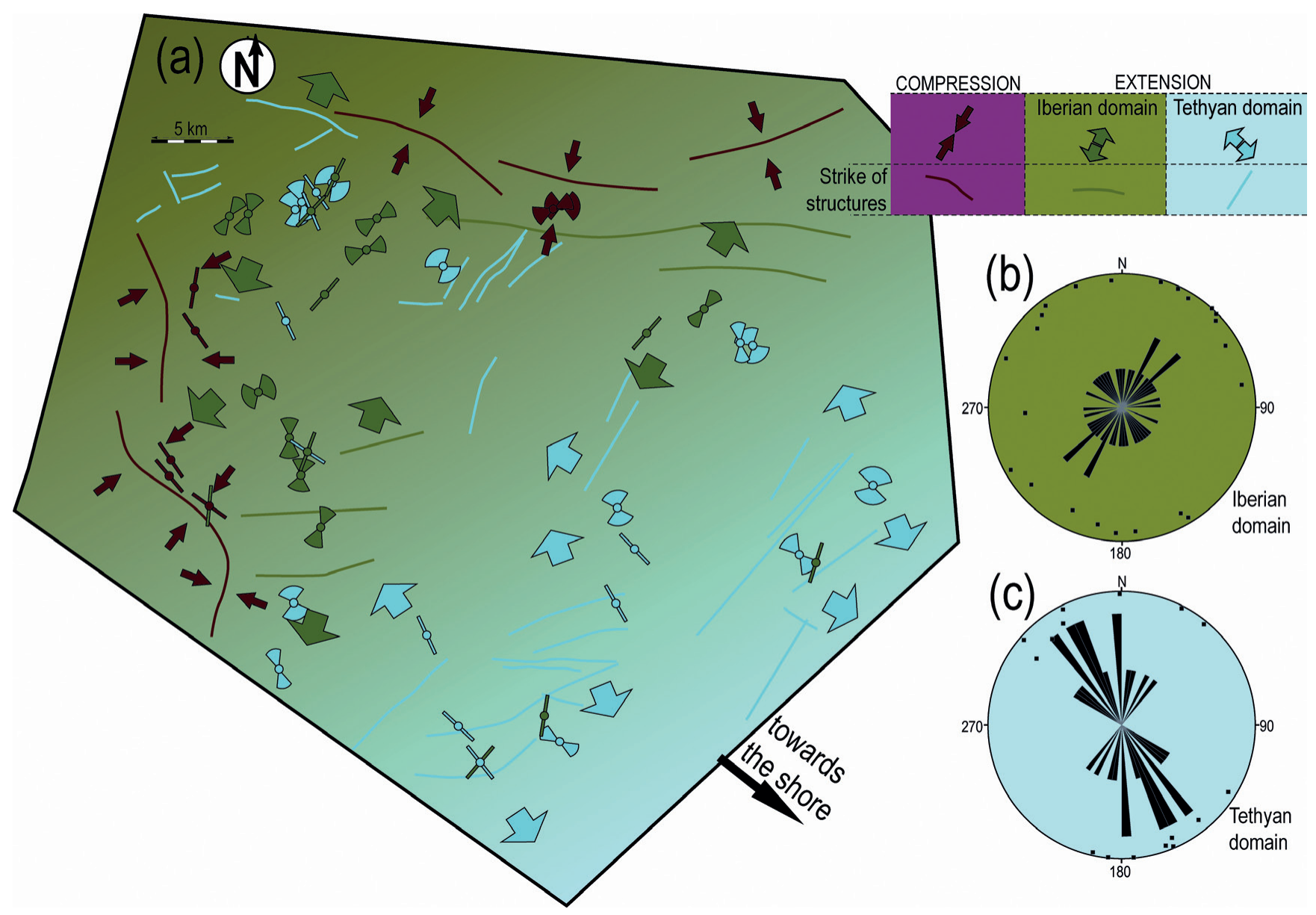

Fig. 12. (a) Sketch interpreting the probable spatial incidence of the main tectonic events in the orientation of the magnetic fabrics in the Maestrat basin. The orientations of the magnetic lineations averaged per site are included and shaded according to their related tectonic event: green, Iberian extension-related sites; blue, Tethyan extension-related sites; red, Cenozoic compression-related sites. For colours, see the online version. (b) Rose diagram of magnetic lineations of sites located in the inward domain of the study area (mainly Iberian extension-related). (c) Rose diagram of magnetic lineations of sites located in the coastward domain of the study area (mainly Tethyan extension-related).

Cretaceous units. Although a certain degree of variability in magnetic lineation orientations is observed, two domains can be differentiated: (1) a northwestern Iberian domain, where magnetic lineations are oriented NE-SW, parallel to the extension direction described for the whole Iberian basin; (2) a southeastern Tethyan domain, where magnetic lineations are NW-SE and NNW-SSE, parallel to the extension direction occurring in the western Tethys margin. The variability in the obtained results demonstrates the particular location of the Maestrat basin, recording the two largescale extensional mechanisms and their influence on the sedimentary and structural configuration of the basin.

Magnetic ellipsoids compared with previous structural information indicate a limited influence of the Cenozoic compression at a few of the AMS sites. They are located in the western and northernmost sectors of the studied region, coinciding with marginal areas of the basin, in which the compressive features are more developed.

\section{Acknowledgements and Funding}

We thank S. Gracia and M. Tricas, from the Servicio General de Apoyo a la Investigación-SAI, Universidad de Zaragoza (Servicio de Preparación de Rocas y Materiales Duros) for the help with AMS measurements and for preparation of thin sections, respectively. We also acknowledge the inestimable help of L. Sagnotti and A. Winkley during the rock magnetism measurements at the INGV. This study was financed by the research projects CGL2009-08969 and CGL2013-42670-P of the MICINN (Spanish Ministry of Science and Innovation). C.G.-L. also acknowledges the MICINN for the research grant BES-2010-037509. This paper was greatly improved after suggestions from C. Stevenson, M. Porreca and two anonymous reviewers.

\section{References}

Alonso, A., Floquet, M., Mas, R. \& Meléndez, A. 1993. Late Cretaceous carbonate platforms: Origin and evolution, Iberian Range, Spain. In: Simó, J.A.T., Scott, R.W. \& Masse, J.P. (eds) Cretaceous Carbonate Platforms. AAPG Special Publications, 56, 297-316.

Álvaro, M., Capote, R. \& Vegas, R. 1979. Un modelo de evolución geotectónica para la Cadena Celtibérica. Acta Geológica Hispánica, 14, 172-177.

Antolín-Tomás, B., Liesa, C.L., Casas, A.M. \& Gil-Peña, I. 2007. Geometry of fracturing linked to extension and basin formation in the Maestrazgo basin (Eastern Iberian Chain Spain). Revista de la Sociedad Geológica de España, 20, 351-365

Aranda, M. \& Simón, J.L. 1993. Aspectos de la tectónica cretácica y terciaria en la cuenca de Utrillas (Teruel) a partir de los datos de minería de interior. Revista de la Sociedad Geológica de España, 6, 123-129.

Aurell, M. 1991. Identification of systems tracts in low-angle carbonate ramps: Examples from the Upper Jurassic of the Iberian Chain (Spain). Sedimentary Geology, 73, 101-115.

Borradaile, G.J. 1988. Magnetic susceptibility petrofabrics and strain. Tectonophysics, 156, 1-20.

Borradaile, G.J. \& Henry, B. 1997. Tectonic applications of magnetic susceptibility and its anisotropy. Earth-Sciences Reviews, 42, 49-93.

Borradaile, G.J. \& Jackson, M. 2004. Anisotropy of magnetic susceptibility (AMS); magnetic petrofabrics of deformed rocks. In: Martín-Hernández, F., Lüneburg, C.M., Aubourg, C. \& Jackson, M. (eds) Magnetic Fabric: Methods and Applications. Geological Society, London, Special Publications, 238, 299-360, http://dx.doi.org/10.1144/GSL.SP.2004.238.01.18.

Borradaile, G.J. \& Tarling, D. 1981. The influence of deformation mechanisms on magnetic fabrics in weakly deformed rocks. Tectonophysics, 77, 151-168.

Canérot, J. 1974. Recherches géologiques aux confins des chaînes Ibérique et Catalane. Doctoral thesis, ENADIMSA, Madrid.

Capote, R., Muñoz, J.A., Liesa, C.L. \& Arlegui, L.E. 2002. Alpine tectonics I: The Alpine system north of the Betic Cordillera. In: Gibbons, W. \& Moreno, T. (eds) Geology of Spain. Geological Society, London, 367-400.

Chadima, M. \& Hrouda, F. 2009. Cureval 8.0: Thermomagnetic Curve Browser for Windows. Agico Inc, Brno. 
Chadima, M. \& Jelinek, V. 2009. Anisoft 4.2: Anisotropy Data Browser for Windows. Agico Inc, Brno.

Cifelli, F., Mattei, M., Chadima, M., Hirt, A.M. \& Hansen, A. 2005. The origin of tectonic lineation in extensional basins: Combined neutron texture and magnetic analyses on 'undeformed' clays. Earth and Planetary Science Letters, 235, 62-78.

Day, R., Fuller, M. \& Schmidt, V.A. 1977. Hysteresis properties of titanomagnetites: Grain size and composition dependence. Physics of the Earth and Planetary Interiors, 13, 260-267.

Dunlop, D.J. 1972. Magnetic mineralogy of unheated and heated red sediments by coercivity spectrum analysis. Geophysical Journal of the Royal Astronomical Society, 27, 37-55.

Dunlop, D.J. \& Özdemir, Ö. (eds) 1997. Rock Magnetism, Fundamentals and Frontiers. Cambridge Studies in Magnetism. Cambridge University Press, Cambridge.

García, R., Moreno-Bedmar, J.A. et al. 2014. Lower Cretaceous (HauterivianAlbian) ammonite biostratigraphy in the Maestrat Basin (E Spain). Journal of Iberian Geology, 40, 99-112.

García-Lasanta, C., Oliva-Urcia, B., Román-Berdiel, T., Casas, A.M. \& Hirt, A.M. 2014. Understanding the Mesozoic kinematic evolution in the Cameros basin (Iberian Range, NE Spain) from magnetic subfabrics and mesostructures. Journal of Structural Geology, 66, 84-101.

GEODE. 2013. Sistema de Información Geológica Contínua: SIGECO. IGME, Madrid [reference date 05/03/2013]. http://cuarzo.igme.es/sigeco/default.htm.

Guimerà, J. 1984. Palaeogene evolution of deformation in the northeastern Iberian Peninsula. Geological Magazine, 121, 413-420.

Guimerà, J., Mas, R. \& Alonso, A. 2004. Intraplate deformation in the NW Iberian Chain: Mesozoic extension and contractional inversion. Journal of the Geological Society, London, 161, 291-303, http://dx.doi.org/10.1144/0016764903-055.

Hirt, A.M. \& Gehring, A.U. 1991. Thermal alteration of the magnetic mineralogy in ferruginous rocks. Journal of Geophysical Research, 96, 9947-9953.

Hrouda, F. \& Jelinek, V. 1990. Resolution of ferrimagnetic and paramagnetic anisotropies in rocks using combined low field and high field measurements. Geophysical Journal International, 103, 75-84

Ihmlé, P.F., Hirt, A.M., Lowrie, W. \& Dietrich, D. 1989. Inverse magnetic fabric in deformed limestones of the Morcles Nappe, Switzerland. Geophysical Research Letters, 16, 1383-1386.

Jelinek, V. 1978. Statistical processing of anisotropy of magnetic susceptibility measured on groups of specimens. Studia Geophysica et Geodaetica, 22, 50-62.

Jelinek, V. 1981. Characterization of the magnetic fabric of rocks. Tectonophysics, 79, 63-70.

Kissel, C., Barrier, E., Laj, C. \& Lee, T. 1986. Magnetic fabric in 'undeformed' marine clays from compressional zones. Tectonics, 5, 769-781.

Kligfield, R., Lowrie, W., Hirt, A. \& Siddans, A.W.B. 1983. Effect of progressive deformation on remanent magnetization of Permian red beds from the Maritime Alps (France). Tectonophysics, 98, 59-85.

Larrasoaña, J.C., Gómez-Paccard, M., Giralt, S. \& Roberts, A.P. 2011 Rapid locking of tectonic magnetic fabrics in weakly deformed mudrocks. Tectonophysics, 507, 16-25.

Liesa, C.L. 2000. Fracturación y campos de esfuerzo compresivos alpinos en la Cordillera Ibérica y el $N E$ peninsular. $\mathrm{PhD}$ thesis, University of Zaragoza.

Liesa, C.L., Soria, A.R. \& Meléndez, A. 1996. Estudio preliminar sobre la tectónica sinsedimentaria del Cretácico inferior en el borde septentrional de la Cubeta de Aliaga (Cordillera Ibérica). Geogaceta, 20, 1707-1710.

Liesa, C.L., Casas, A.M., Soria, A.R., Simón, J.L. \& Meléndez, A. 2004 Estructura extensional cretácica e inversión terciaria en la región de AliagaMontalbán. In: Colombo, F., Liesa, C.L., Meléndez, G., Pocoví, A., Sancho, C. \& Soria, A.R. (eds) Itinerarios Geológicos por Aragón. Geo-Guías, Zaragoza, 151-180.

Lowrie, W. 1990. Identification of ferromagnetic minerals in a rock by coercivity and unblocking temperature properties. Geophysical Research Letters, 17, 159-162.

Lüneburg, C.M., Lampert, S.A., Hermann, I., Lebit, D., Hirt, A.M., Casey, M. \& Lowrie, W. 1999. Magnetic anisotropy rock fabrics and finite strain in deformed sediments of SW Sardinia (Italy). Tectonophysics, 307, 51-74.

Martín-Chivelet, J., Berástegui, X. et al. 2002. Cretaceous. In: Gibbons, W. \& Moreno, T. (eds) The Geology of Spain. Geological Society, London, 255-292.

Martín-Martín, J.D., Gomez-Rivas, E. et al. 2013. The Upper Aptian to Lowe Albian syn-rift carbonate succession of the southern Maestrat Basin (Spain): Facies architecture and fault-controlled stratabound dolostones. Cretaceous Research, 41, 217-236.

Mas, R. \& García, A. 2004. Segunda fase de rifting: Jurásico SuperiorCretácico Inferior. In: Vera, J.A. (ed.) Geología de España. SGE-IGME, Madrid, 503-510

Mattei, M., Sagnotti, L., Faccenna, C. \& Funiciello, R. 1997. Magnetic fabric of weakly deformed clay-rich sediments in the Italian peninsula: Relationship with compressional and extensional tectonics. Tectonophysics, 271, 107-122.

Mattei, M., Speranza, F., Argentieri, A., Rosseti, F., Sagnotti, L. \& Funiciello, R. 1999. Extensional tectonics in the Mantea basin (Calabria, Italy): A comparison between structural and magnetic anisotropy data. Tectonophysics, 307, 33-49.

Néel, L. 1948. Propriétés magnétiques des ferrites. Férrimagnétisme et antiferromagnétisme. Annales de Physique, 3, 137-198

Oliva-Urcia, B., Román-Berdiel, T., Casas, A.M., Pueyo, E.L. \& Osácar, C. 2010a. Tertiary compressional overprint on Aptian-Albian extensional magnetic fabrics, North-Pyrenean Zone. Journal of Structural Geology, 32, 362-376.

Oliva-Urcia, B., Casas, A.M., Soto, R., Villalaín, J.J. \& Kodama, K. 2010b. A transtensional basin model for the Organyà basin (central Southern Pyrenees) based on magnetic fabric and brittle structures. Geophysical Journal International, 184, 111-130.

Oliva-Urcia, B., Román-Berdiel, T., Casas, A.M., Bógalo, M.F., Osacar, M.C. \& García-Lasanta, C. 2013. Transition from extensional to compressional magnetic fabrics in the Cretaceous Cabuérniga basin (North Spain). Journal of Structural Geology, 46, 220-234.

Olivet, J.L. 1996. La cinématique de la plaque ibérique. Bulletin des Centres de Recherches Exploration-Production Elf-Aquitaine, 20, 131-195.

Parés, J.M., Van der Pluijm, B.A. \& Dinarès-Turell, J. 1999. Evolution of mag netic fabrics during incipient deformation of mudrocks (Pyrenees northern Spain). Tectonophysics, 307, 1-14

Querol, X., Salas, R., Pardo, G. \& Ardèvol, L. 1992. Albian coal-bearing deposits of the Iberian Range in Northeastern Spain. In: McCabe, J.P. \& Parrish, J.T. (eds) Controls and Distribution and Quality of Cretaceous Coals. Geological Society of America, Special Papers, 267, 193-208.

Ritcher, C. \& Van der Pluijm, B.A. 1994. Separation of paramagnetic and ferrimagnetic susceptibilities using low temperature magnetic susceptibilities and comparison with high field methods. Physics of the Earth and Planetary Interiors, 82, 113-123.

Robion, P., Grelaud, S. \& Frizon de Lamotte, D. 2007. Pre-folding magnetic fabrics in fold and thrusts belts: Why the apparent internal deformation of the sedimentary rocks from the Minervois basin (NE Pyrenees, France) is so high compared to the Potwar basin (SW Himalaya, Pakistan)? Sedimentary Geology, 196, 181-200

Roca, E. \& Guimerà, J. 1992. The Neogene structure of the eastern Iberian margin: Structural constraints on the crustal evolution of the Valencia trough (western Mediterranean). Tectonophysics, 203, 203-218.

Roca, E., Guimerà, J. \& Salas, R. 1994. Mesozoic extensional tectonics in he southeast Iberian Chain. Geological Magazine, 131, 155-168.

Rochette, P. 1987. Magnetic susceptibility of the rock matrix related to magnetic fabric studies. Journal of Structural Geology, 9, 1015-1020.

Rochette, P., Jackson, M. \& Aubourg, C. 1992. Rock magnetism and the interpretation of anisotropy of magnetic susceptibility. Reviews of Geophysics, 30, 209-226.

Rodríguez-López, J.P., Liesa, C.L., Meléndez, N. \& Soria, A.R. 2006. Tectónica extensiva sinsedimentaria de la Fm Escucha en el sector meridional de la subcuenca cretácica de Oliete (Cadena Ibérica oriental). Revista de la Sociedad Geológica de España, 19, 99-112.

Sàbat, F., Roca, E. et al. 1995. Role of extension and compression in the evolution of the eastern margin of Iberia: The ESCI-Valencia Trough seismic profile. Revista de la Sociedad Geológica de España, 8, 431-448.

Sagnotti, L., Winkler, A. et al. 1999. Magnetic anisotropy of Plio-Pleistocene sediments from the Adriatic margin of the northern Apennines (Italy): Implications for the time-space evolution of the stress field. Tectonophysics, 311, 139-153.

Salas, R. \& Casas, A. 1993. Mesozoic extensional tectonics, stratigraphy and crustal evolution during the Alpine cycle of the eastern Iberian basin. Tectonophysics, 228, 33-55.

Salas, R., Guimerà, J., Mas, R., Martín-Closas, C., Meléndez, A. \& Alonso, A. 2001. Evolution of the Mesozoic Central Iberian Rift System and its Cenozoic inversion (Iberia Chain). In: Ziegler, P.A., Cavazza, W., Robertson, A.F.H \& Crasquin-Soleau, S. (eds) Peri-Tethyan Rift/Wrench Basins and Passive Margins. Mémoires du Muséum National d'Histoire Naturelle, 186, 145-185.

Simón Gómez, J.L. 1984. Compresión y distensión alpinas en la Cadena Ibérica oriental. $\mathrm{PhD}$ thesis, Zaragoza University.

Simón, J.L., Arlegui, L.E., Lafuente, P. \& Liesa, C.L. 2012. Active extensional faults in the central-eastern Iberian Chain, Spain. Journal of Iberian Geology, 38, 127-144.

Soria, A.R., Martín-Closas, C., Meléndez, A., Meléndez, M.N. \& Aurell, M. 1995. Estratigrafía del Cretácico inferior continental de la Cordillera Ibérica Central. Estudios Geológicos, 51, 141-152.

Soria, A.R., Meléndez, A., Aurell, M., Liesa, C.L., Meléndez, M.N. \& Gómez-Fernández, J.C. 2000. The Early Cretaceous of the Iberian Basin (Northeastern Spain). In: Gierlowski-Kordesch, E.H. \& Kelts K.R. Lake Basins through Space and Time. AAPG Studies in Geology, 46, 257-262.

Soto, R., Casas-Sainz, A.M., Villalaín, J.J. \& Oliva-Urcia, B. 2007. Mesozoic extension in the Basque-Cantabrian basin (N Spain): Contributions from AMS and brittle mesostructures. Tectonophysics, 445, 373-394.

Soto, R., Casas-Sainz, A.M. et al. 2008. Characterizing the Mesozoic extension direction in the northern Iberian plate margin by anisotropy of magnetic susceptibility (AMS). Journal of the Geological Society, London, $\mathbf{1 6 5}$, 1007-1018, http://dx.doi.org/10.1144/0016-76492007-163.

Tarling, D.H. \& Hrouda, F. 1993. The Magnetic Anisotropy of Rocks. Chapman \& Hall, London.

Tauxe, L. 2008. Essentials of Paleomagnetism. University of California Press, Berkeley, CA.

Wieckzorek, J. 1979. Geopetal structures as indicators of top and bottom. Annales de la Société Géologique de Pologne, 49, 215-221.

Ziegler, P.A. 1989. Geodynamic model for Alpine intraplate compressional deformation in Western and Central Europe. In: Cooper, M.A. \& Williams, G.D. (eds) Inversion Tectonics. Geological Society, London, Special Publications, 44, 63-85, http://dx.doi.org/10.1144/GSL.SP.1989.044.01.05. 